\title{
Labor Market Assimilation of Recent Immigrants in Spain
}

\author{
Catalina Amuedo-Dorantes \\ Department of Economics \\ San Diego State University \& IZA \\ e-mail: camuedod@mail.sdsu.edu \\ Sara de la Rica \\ Depto. Fundamentos del Análisis Económico II \\ Universidad del País Vasco \& IZA \\ e-mail: sara.delarica@ehu.es
}

\begin{abstract}
This paper provides a preliminary analysis of the employment and occupational assimilation of recent immigrant waves to the Spanish labor market as their residencies lengthen. Using Spanish data from the 2001 Population Census and the 2002 Earnings Structure Survey, we find evidence of immigrant employment and occupational assimilation significantly varying by gender, origin and educational attainment. For instance, EU15 immigrants do not display an employment or occupational gap with respect to natives, whereas immigrants originating from non-EU15, African or Latin American countries do. Yet, among the latter, non-EU15 and Latin American immigrants assimilate employment and occupation-wise, while there is limited evidence of labor market assimilation among African immigrants.
\end{abstract}

Keywords: immigrant assimilation, employment, occupational attainment and mobility, Spain.

JEL: J61. 


\section{Introduction}

Migration remains nowadays one of the most important topics of interest in Population Economics. Academic research regarding migration has concentrated on the following issues: (a) the effect of immigrant on natives, (b) migration policy, (c) the determinants of migration, and (d) assimilation of migrants. The study herein is focused on the last of these four topics. In this regard, and since the seminal work of Chiswick (1978), a great deal of attention has been dedicated to assessing the labor market performance of immigrants relative to that of natives as they integrate to their host country. This is undoubtedly an important issue from both a social and economic point of view for every country with a non-negligible immigration rate. In the case of Spain, where immigration has been increasing at an impressive pace during the past decade, a better understanding of how immigrants assimilate as their residence lengthens becomes crucial.

Preliminary findings by Chiswick (1978) for the United States found that while immigrants earned significantly less than natives upon their arrival, they caught up with natives in terms of earnings as they integrated in the host country. Chiswick (1978) used cross-sectional studies and compared the earnings of immigrants relative to natives of different cohorts. However, these findings were later questioned by Borjas $(1985,1995)$ on the basis that cross-section studies assumed that the quality of immigrants across cohorts did not change; an assumption that Borjas (1985) refuted. Borjas showed that the quality of immigrants in the U.S. had declined over the decades and, as a result, assimilation was not taking place as rapidly as Chiswick (1978) suggested. Additional studies examining the assimilation of immigrants to countries other than the United States 
include Longva and Raaum (2001) for Norway, Hartog and Winkelmann (2002) for the Netherlands, Bevelander and Nielsen (2000) for Sweden, Constant and Massey (2003) for Germany, and Wheatly Price (1999) for the U.K., among others. As of today, there is no empirical study on the labor market assimilation of immigrants in Spain.

This paper attempts to fill up this gap by focusing on two aspects of the labor market assimilation of immigrants. First, we examine immigrants' employment assimilation as captured by changes in the employment probability differential between similar immigrants and natives as immigrants' stay in Spain lengthens. This issue has been treated, among others, by Bevelander and Nielsen (2000) in Sweden and Wheatley Price (1999) in the U.K. Secondly, we look at the assimilation occupation-wise of employed immigrants. We rank occupations on the basis of their average earnings according to the 2002 Spanish Earnings Structure Survey. Subsequently, we analyze immigrants' occupational assimilation as their residencies in Spain lengthen relative to similarly skilled natives. The analysis is carried out separately by gender so as to uncover differences in the economic adaptation of male and female immigrants. In addition, we differentiate immigrants according to their place of origin. In Spain, ninety percent of immigrants originate from Europe (from a EU15 country member or not), Africa and Latin America.

The paper is organized as follows. The next section describes the recent trends in immigration in the Spanish case and provides a general characterization of recent immigrants. Section 3 discusses the methodology, whereas section 4 contains a description of the data used for the analysis. Section 5 presents the results and section 6 concludes the study. 


\section{Immigration in Spain}

\subsection{Recent Immigration Trends}

Spain has been traditionally a country of emigrants. During the 1850-1953 period, approximately 3.5 million Spaniards left for the Americas from regions such as Galicia, Asturias and the Canary Islands. Argentina, Uruguay, Brazil and Cuba were some of the most popular destinations of these emigrants. Spanish migrants also went to Africa from areas such as Murcia and the Balear Islands, although to a lesser extent. However, Spain witnessed some significant changes in its migration patterns during the $20^{\text {th }}$ century. First, about 74 percent of Spanish emigrants chose Northern Europe as their destination between mid 1950s and mid 1970s. Second, from the mid 1970s onwards, Spain became the host country of foreign laborers from Northern Africa and LatinAmerica. Out migration diminished during the international economic crisis of the early seventies, whereas immigration grew at a steady pace. The transition from an immigrantsending to an immigrant-receiving country was the byproduct of a larger shift in regional migration patterns. By the late 1980s and early 1990s, Mediterranean countries, such as Spain, Portugal and Italy, became immigrant-receiving nations due to a variety of factors, such as: (1) their geographical proximity to immigrant-sending regions, e.g. Africa; (2) the barriers to immigration in traditionally immigrant-receiving nations during the 1950s, 1960s, and part of the 1970s, as it was the case in Germany, Switzerland and France; and (3) the improved economies of Mediterranean countries.

At any rate, the largest immigration flow has taken place from the mid nineties onwards. Immigrants from Europe, Africa and Latin America account for approximately 92 percent of all recent immigrants. Figure 1 shows the changing composition of the 
immigrant inflow from 1995 to 2004. ${ }^{1}$ Although Europeans used to account for half of all immigrants in 1995, the flow of immigrants from Latin American and Africa has increased at a faster rate after the year 2000, catching up with European immigrant flows by the year 2004 .

These recent and growing immigrant flows pose some questions regarding their assimilation to the Spanish labor market. A better understanding of these two aspects of immigrants' economic integration is, indeed, crucial in the development of social policies facilitating the integration of these newcomers to the Spanish society. However, we first discuss some of the key features of Spanish immigration law during the period covered by our analysis, i.e., 1997-2001.

\subsection{Key Features of Spanish Immigration Law (1997-2001)}

The first piece of legislation regulating immigrant rights in Spain was passed on July 1985 when immigration flows were still small relative to those of EU nations like Germany, France or Belgium. That law regulated relatively restrictive entry criteria for immigrants, such as short lasting residence and work permits. Additionally, despite paying social security taxes when employed, the law did not recognize immigrants the right to enjoy any social benefits. In an attempt to update the legislation, a new law, Law 8/2000, was approved by Congress in the year 2000. The new law addressed the regulation of new entry and work permit criteria similar to those in place in other EU country members. However, extraordinary immigrant regularizations or amnesties granted by the government have emerged as the most common via of getting work permits during the past two decades following the regularizations of 1986, 1991, 1996,

\footnotetext{
${ }^{1}$ Figure 1 refers to immigrants with residence permits in each of the plotted years.
} 
and the year 2000. In fact, as a result of two amnesties granted in the year 2000, a total of 400,000 immigrants regularized their statuses between 2000 and 2002. In order to become legal aliens, immigrants had to provide proof of one of the following: (1) residence since June 1, 1999, (2) having held a work permit anytime during the three year period preceding February 1, 2000, (3) being denied asylum before February 2000, (4) having applied for any type of residence permit before March 30, 2000, or (5) family ties to legal residents or to individuals in any of the previous circumstances.

\section{Methodology}

The purpose of this study is to examine the assimilation process of recent immigrant waves to the Spanish labor market. We focus on two crucial aspects of labor market assimilation as is the case with employment and occupational attainment of immigrants relative to natives as their residence lengthens. With this intent, we confine our analysis to individuals in the labor force. Once searching, immigrant $i$ will work if the offered market wage, $w_{i}$, exceeds the reservation wage, $w_{i}^{r}$. We can thus define the following index function:

$$
I_{i}=w_{i}-w_{i}^{r}=X_{i} \beta+\varepsilon_{i}
$$

where if $I_{i}>0$, the individual will choose to work and s/he will remain unemployed otherwise. Consequently, the employment likelihood is given by:

(2) $P_{i}=\operatorname{Pr}\left(I_{i}>0\right)=\operatorname{Pr}\left(\varepsilon_{i}>-X_{i} \beta\right)$ where: $\varepsilon_{i} \sim N(0,1)$,

where $X_{i}$ is a vector of socioeconomic characteristics affecting labor market earnings, such as: age -a proxy for labor market experience, marital status and relationship to the household head, educational attainment, and region of residence. 
Our main interest rests on the estimated employment probability of immigrants relative to native-born individuals, which can be assessed by including an immigrant dummy in the vector $X_{i}$. Additionally, we are interested in learning about immigrant's assimilation to natives as their residence lengthens. Immigrants accumulate country specific human capital -including language skills for those originating from non-Spanish speaking countries- as the number of years elapsed since migration increases. Therefore, the vector $X_{i}$ also incorporates information on immigrants' years of residence in Spain to capture the expected positive correlation between years since migration and the employment likelihood of immigrants.

However, as pointed out by Borjas (1985), a single cross-section estimation of equation (2) will not help us assess the employment assimilation of immigrants unless it is assumed that the quality of immigrant cohorts has remained unchanged. This is not an unrealistic assumption in the Spanish case given the recent nature of Spanish immigration. Up to the mid 1970s, Spain had experienced more out-migration than immigration. In fact, the vast majority of immigrant flows have occurred during the late 1990s and early in the 21st century, resulting in a relatively short period of time for the quality of immigrant cohorts to have substantially differed. At any rate, we restrict our analysis to employed and unemployed natives and immigrants with no more than five years of residence in Spain as of 2001 so as to guarantee their similarity in terms of quality. This amounts to considering immigrants arriving in 1997 or later; an immigrant stock that accounts for approximately 60 percent of all immigrants. ${ }^{2}$ As such, we avoid including immigrants who may have been affected by the 1996 extraordinary

\footnotetext{
${ }^{2}$ Adding those immigrants who arrived during the first half of the nineties would only increase the fraction of overall immigrants by 12 percentage points.
} 
regularization or amnesty and lessen any deterministic biases created by return migration. ${ }^{3}$

Using this sample, we estimate equation (2) jointly for natives and immigrants. We carry out the estimation separately by gender and by immigrants' origin to address their differential employment patterns. Subsequently, we use the coefficient estimates from equation (2) to derive the predicted employment probabilities for a representative immigrant and native, $\hat{P}_{I}$ and $\hat{P}_{N}$ respectively, evaluated at $\bar{X}$. We also report the predicted employment probabilities for immigrants if they had the same characteristics as natives. In this manner, we are able to more accurately report differences in the employment likelihood of natives relative to immigrants net of any differences in their observed skills. The following term gives an estimate of immigrants' assimilation to natives in terms of their employment likelihood, $\hat{P}$, as their residencies lengthen:

$$
\hat{P}_{I, 5 y \text { rs }}-\hat{P}_{I, 0 \text { yrs }}=\left(\hat{P}_{N}-\hat{P}_{I, 0 \text { yrs }}\right)-\left(\hat{P}_{N}-\hat{P}_{I, 5 y r s}\right) \text {. }
$$

Yet, the figures from equation (3) do not enable us to assess the quality of the job found as reflected, for instance, by its occupational rank. There is no easy way to rank occupations since many job attributes are difficult to compare. While cognizant of this limitation, we assume that it is possible to rank occupations based on their remuneration. This assumption allows us to work with a variety of occupations and a simple framework according to which, once employed, the probability that immigrant $i$ 's occupation has rank $k=j$ is given by the probability that the score -estimated as a linear function of the

\footnotetext{
${ }^{3}$ It is worth noting that the direction of the biases caused by return migration is not always obvious. On the one hand, it is possible that migrants who experience hardships upon arrival to the host country are the ones returning home. Alternatively, it may be the case that these migrants are the ones encountering a greater difficulty to return to their distant countries. As such, they are the ones to stay longer relative to more successful migrant who may choose to go back to their countries after successfully working and saving enough money in the host country.
} 
migrant's personal characteristics and returns at various occupational ranks- plus the random error is within the range of cutoff points estimated for that specific rank $j$ as follows:

$$
\operatorname{Pr}\left(\text { rank of } \text { occupation }_{i}=j\right)=\operatorname{Pr}\left(k_{j-1}<X_{1 i} \alpha_{1}+\ldots+X_{K i} \alpha_{K}+v_{i} \leq k_{j}\right)
$$

where $k=1, \ldots j, \ldots \mathrm{K}$ is the number of possible ranks in the model. Since the Population Census lacks information on workers' earnings, we use data from the 2002 Spanish Earnings Structure Survey to devise an occupational ranking. In particular, we assign the lowest rank order $(k=1)$ to the occupation with the lowest average hourly wage and assign the highest rank order $(k=\mathrm{K})$ to the occupation with the largest average hourly wage. Assuming that the vector $v_{i}$ in equation (4) is assumed to be logistically distributed according to an ordered logit, we can estimate equation (4) as an ordered logit. The vector $X_{i}$ contains a dummy for foreign-born as well as information on years of Spanish residency. Therefore, we are able to explore how immigrants assimilate to natives in terms of their occupational attainment as well as immigrants' occupational mobility. The analysis is carried out separately by gender and by immigrant origin. To facilitate the interpretation of the results, we report the odds ratios computed as: odds $\left({\left.\text { rank of } \text { occupation }_{i}=j\right)=P(\text { rank of occupation }}_{i}>j\right) / P\left(\right.$ rank of occupation $\left._{i} \leq j\right)$. Odds ratios are the ratios of the odds in two groups of interest. If the odds ratio is, for example, 0.75 , it means that the outcome is 25 percent less likely among immigrants relative to natives. In contrast, an odds ratio of 1.33 means that the outcome is 33 percent more likely among immigrants than natives. 


\section{Data and Some Descriptive Statistics}

\subsection{The Data}

We use data from the 2001 Population Census. The Census has the advantage of, in principle, interviewing all immigrants independent of their legal status. Nonetheless, we are aware that an important fraction of unauthorized immigrants may not fill in the questionnaire and, as such, this group is likely to be under-represented in the Census. The 2001 Population Census was fielded by the Spanish Institute of Statistics during the last term of 2001. Around 13 million households and 40 million individuals were interviewed. The Census gathers information on personal and demographic characteristics (such as age, education, marital status, relationship to the household head, or province) and job characteristics (such as work status, occupation, and industry). In addition, for immigrants - defined as individuals reporting a foreign nationality, the Census collects information on the number of years elapsed since entry and on the country of origin.

Our sample consists of individuals in the workforce on account of our interest in assessing immigrant assimilation to alike natives in terms of employment and occupational attainment. Moreover, in order to ensure the comparability of immigrants’ performance in terms of cohort quality, we focus on recent immigrants with up to five years of residence in Spain, who accounted for almost 60 percent of the immigrant stock in 2001.

Finally, given the lack of information on labor earnings in the Population Census, we extract average hourly wage data for each of the occupations in the 2002 Earnings Structure Survey -known by its acronym of EES-02. The EES-02 contains individual 
information on 169,520 full-time workers (117,161 men and 52,359 women) from 21,621 establishments. The EES-02 survey includes a random sample of establishments in the manufacturing, construction and service industries. In addition to establishment level information, the survey collects individual level data on gross hourly wages and occupations held by workers at the two-digit ISCO-88 level. As such, we are able to construct average hourly wages for each of those occupations and use that information to rank occupations as explained in the methodology section.

\subsection{Native and Recent Immigrant Profiles}

Table 1 displays some key features of the population object of study. On average, immigrants in our sample are 32 years old or between 4 and 6 years younger than their native counterparts. The incidence of household head status is about the same for natives and most immigrants. The exception is women from EU15 countries, fifty-five percent of who are household heads relative to an average 31 to 37 percent in the case of other immigrants or natives, respectively.

Residence-wise, immigrants have been an average of 2 years in Spain. EU15 and African immigrants display the longest residencies (in the order of 2.3 to 2.7 years), whereas non-EU15 and Latino immigrants display the shorter residencies. Additionally, immigrants display an educational attainment similar to that of natives. However, when distinguishing by region of origin, we uncover significant differences across immigrant groups. For instance, more than 50 percent of African immigrants only have primary education relative to less than 25 percent of natives and most other immigrant groups. In contrast, more than 30 percent of EU15 immigrants have a university degree relative to 16 and 26 percent of male and female natives, respectively. The remaining immigrant 
groups display a significantly lower incidence of college education than comparable natives.

Lastly, employment-wise, male immigrants endure higher unemployment rates approximately 7 percentage points higher, on average- than native men. In contrast, immigrant and native women display similar employment rates, in the order of 20 percent. Yet, by immigrant origin, African women endure the highest unemployment rates, i.e. 22 to 25 percent.

\section{Immigrant Labor Market Assimilation}

\subsection{Immigrant Employment Assimilation}

Tables 2 and 3 display the maximum likelihood estimates of equation (2) for the immigrant dummy and for the vector of years-since-migration dummies which are of interest to this study. The omitted variable (comparison group) is a native and, once we focus on immigrants' employment assimilation according to the length of their residencies, immigrants with less than 1 year since migration are used as reference. A couple of findings are worth discussing. First, immigrant men and women are significantly less likely to be employed than similar natives. On average, recent male and female immigrants (i.e. with less than one year of residence) endure a 14 percentage point and a 7 percentage point lower likelihood of employment than comparable natives, respectively. The magnitude of these employment gaps not only differs according to gender, but also depending on immigrants' origin. Specifically, immigrant men from non-EU15 countries endure the largest employment gap with respect to similar natives, i.e. in the order of 17 percentage points. In contrast, African immigrants are only 10 percentage points less likely to be employed than comparable natives. Among women, 
recent immigrants from the EU15 countries display the largest employment gap with respect to similar natives (in the order of 16 percentage points), whereas recently arrived Latino women are only 6 percentage points less likely to be employed than alike natives. As we shall discuss in what follows, certain immigrant groups may have lower reservation wages than others. In those instances, differences in the employment likelihood may not function as good indicators of immigrant assimilation.

A second finding from the figures in Tables 2 and 3 refers to the assimilation rate of immigrants to natives as the number of years since migration lengthens. In this regard, Tables 4a to Table 4c summarize some key findings. Specifically, according to the figures in Table 4a, the employability gap between male immigrants and their native counterparts narrows from 17 percentage points when immigrants first arrive to the country to about 3 percentage points five years later. Yet, the largest employment gap reduction occurs within the first year of residence, when the gap narrows from 17 percentage points to 6 percentage points.

Because part of the employment gap between natives and immigrants may be explained by differences in their skills, we re-calculate the predicted employment gap when immigrant men have the same observable characteristics of native men. This gap is reported in the last column of Table 4a. Not surprisingly, the predicted employment gap between natives and immigrants is then reduced to 14 percentage points from the 17 percentage point gap when their characteristics differ. In fact, immigrants, as a whole, are practically able to close their employment gap with respect to comparable natives within two years after migration. 
In addition to differences in their skills, immigrant assimilation in terms of employment also varies according to immigrants' origin. Men's employability gap closes at the fastest rate between native men and their non-EU15 counterparts, who enjoy a higher likelihood of being employed than alike natives by the third year of residence. In contrast, African men endure the slowest assimilation rate of all immigrant groups. Despite being able to cut down their employment gap with respect to similar natives by 12 percentage points within a five year period, African men still endure a 5-percentage point lower employment likelihood than alike natives five years later. However, it is worth pointing out that much of this employment gap is likely to be explained by differences in the skills of native and African men. Indeed, the last column of Table 4a indicates that the employment likelihood of African men would have stood at 9 percentage points less than for alike natives upon arrival to Spain have they had the same characteristics. Furthermore, this gap would have disappeared by the second year after migration if they both had the same characteristics.

Table $4 \mathrm{~b}$ informs on the employment assimilation of immigrant women, for whom assimilation appears to take place at a faster pace than for men. The predicted employment gap between native women and their immigrant counterparts upon arrival is 9 percentage points. However, on average, this gap disappears within the first year after migration, with the predicted likelihood of being employed of immigrant women exceeding that of their native counterparts thereafter. Immigrant women from European countries outside the EU15 and their Latino counterparts are able to close their employment gap relative to similar native women one year after migration. As such, five years later, these immigrant women enjoy a 7 to 8 percentage point higher likelihood of 
being at work than their native counterparts. In contrast, African women endure the largest gap in their predicted employment likelihood with respect to similar natives; a gap that persists five years after migration. Yet, in most instances, any employment differences between native and immigrant women upon arrival are diminished as we compared immigrant women with the same characteristics of their native counterparts. In fact, immigrant women then appear more likely to be at work than native women.

Finally, Table 4c displays the employment assimilation that takes place for each immigrant group over the course of five years. During that time period, immigrant men and women improve their employment likelihood by an average of 14 percentage points. As noted in the discussion of Table 4a, immigrant men from countries outside the EU15 block as well as Latino immigrants assimilate at a faster rate than the average immigrant, whereas African men and immigrant men from EU15 countries improve their employment likelihood at a slower rate. Likewise, African women experience a slow advancement when it comes to their likelihood of finding a job, whereas women from EU15 countries experience a quicker than average assimilation employment-wise.

\subsection{Immigrant Assimilation in Terms of Occupational Attainment and Mobility}

\subsubsection{Some Descriptive Evidence by Gender and Educational Attainment}

The results from Tables 2 through 4 indicate that immigrants are, indeed, less likely than similarly skilled native-born individuals to be employed. However, assimilation does seem to occur, with the likelihood to find a job increasing with the time spent in Spain. Furthermore, the results reveal significant differences by gender and immigrants' origin. Specifically, immigrant men from non-EU15 countries endure the largest employment gap with respect to similar natives, whereas African immigrants are 
only 10 percentage points less likely to be employed than comparable natives. Among women, recent immigrants from the EU15 countries are 16 percentage points less likely to be employed than similar natives, while recently arrived Latino women are only 6 percentage points less likely to be at work than alike natives. This finding, which in the case of Latino migrants may in part be due to their knowledge of the Spanish language, ${ }^{4}$ could also be explained by the different reservation wages of various immigrant groups on account of the earnings' differential between Spain and their home countries. Under such scenario, African men and Latino women may accept jobs quicker than their more highly educated native and EU15 counterparts. However, their jobs may be of higher quality than those held by other immigrant groups in terms of earnings.

In order to make some inferences about the quality of the jobs held by immigrants in our sample, we have first ranked all occupational categories displayed in the 2002 Census in terms of their aggregate average hourly wage. Due to the lack of information on labor earnings in the Census, we use average hourly wages for each of the occupational categories of interest from the 2002 Spanish Survey on the Structure of Earnings. Given their small number of observations, some occupations are bundled together to ensure that all categories have, at the minimum, two percent of the overall number of immigrants in the Census sample. ${ }^{5}$ Altogether, our ranking of occupations takes values ranging from 1 to 22 in the case of men and from 1 to 17 in the case of women, with the worst paid occupation taking the value of 1 .

Table 5 presents the mean occupational rank for natives and immigrants in our sample. In the latter case, we distinguish according to immigrants' origin and length of

\footnotetext{
${ }^{4}$ Unfortunately, the 2001 Census does not provide information on the Spanish fluency of immigrants.

${ }^{5}$ Bundling is always done with the next higher ranked occupational category.
} 
residence in Spain. Native men occupy higher ranked jobs than their immigrant counterparts, even when compared to immigrants with five years of residence. Originwise, EU15 male immigrants work, on average, in higher ranked occupations than their native counterparts and, perhaps as a byproduct of their higher rank, they do not experience as much upward occupational mobility as other immigrant groups. In contrast, African men not only perform worse than native men occupation-wise but, furthermore, experience the least upward mobility. As their male counterparts, native women hold, for the most part, higher ranked occupations than most immigrant women the exception being EU15 women. In contrast, African women work at lower ranked occupations than native women and endure a practical lack of upward occupational mobility.

Further descriptive evidence on native and immigrant occupational attainment is provided in Figure 2 through Figure 9. These figures display the occupational distribution of natives, recent immigrants (with zero or one year of residence) and nonrecent immigrants (with four or five years of residence). The ranking of occupations is measured in the X-axis. Figures 2 through 5 display the occupational distribution of all men and of men with varying educational attainment (primary, secondary, and university). Figures 6 through 9 do the same for working women. Distinguishing men’s and women's occupational attainment according to their educational background is of interest as we should expect assimilation rates to be inversely related to educational attainment. 


\section{A) Occupational Assimilation by Gender}

What is the empirical evidence regarding the occupational assimilation of all immigrant men and women in Figures 2 and 6, respectively? Reading Figure 2, we can conclude that roughly 40 percent of recent immigrants are concentrated in the five worse paid occupations. This percentage compares to 30 percent of non-recent immigrants and an even lower 12 percent of natives. In contrast, the concentration of natives is significantly higher at the opposite tail of the occupational distribution, where approximately 30 percent of natives can be found in the five better paid occupations. Yet, only 18 percent of non-recent immigrants and an even smaller 11 percent of recent immigrants are found in those occupations. Therefore, Figure 2 supports the notion that native men display a higher occupational attainment than immigrant men. Nonetheless, the fact that non-recent immigrants are better-off occupation-wise than their recent counterparts suggests the existence of some upward occupational mobility as immigrants' residencies lengthen.

Figure 6 tells a similar story for women, with the exception that, relative to men, working women are significantly segregated into lower paid occupations. Yet, as in the case of men, we find that approximately 72 percent of recent immigrants work in the five worse paid occupations relative to 60 percent of non-recent immigrants and 34 percent of natives. In contrast, up to 32 percent of native women work in the five better paid occupations as compared to 18 percent of non-recent female immigrants and a small 10 percent of recent female immigrants. Consequently, as for men, there seems to be some evidence of higher occupational attainment among native women combined with some 
upward occupational mobility on the part of female immigrants as their Spanish residencies grow longer.

\section{B) Occupational Assimilation by Educational Attainment}

Do immigrant assimilation rates differ with educational attainment? The answer is yes. In the case of men, assimilation seems to take place at a slower pace for less educated immigrants than for their more educated counterparts. For instance, the small occupational differences between recent and non-recent immigrants in Figure 3 are in sharp contrast with the greater dispersion in the occupational distribution of workers reflected in Figure 5. Indeed, among highly educated men, two percent of natives, eight percent of non-recent immigrants and 13 percent of recent migrants are concentrated in the five worse paid occupations. These percentages compare to 68 percent of natives, fifty-three percent of non-recent immigrants and 46 percent of recent migrants in the five better paid occupations. The greater dispersion in the occupational distribution in Figure 5 hints at the greater upward occupational mobility enjoyed by highly educated immigrant men.

Similar findings are reported by Figures 7 through 9 for women. According to Figure 7, there is a large disparity in the occupational attainment of native women relative to immigrant women. For instance, sixty-five percent of native women are employed in the five lowest paid occupations as compared to 83 percent of immigrant women irrespective of their residencies. While these disparities between immigrant and native occupational attainment still persist regardless of women's educational attainment in Figures 8 and 9, there seems to exist more evidence of upward occupational mobility among more highly educated women. For example, according to Figure 8, only 6 percent 
of native women are employed in the five worse paid occupations as compared to 27 percent of non-recent and 45 percent of recent immigrants. Yet, sixty-six percent of native women, forty-four percent of non-recent immigrant women and 31 percent of recent migrant women are employed in the five better-paid occupations. As such, while native women still reflect a significantly higher occupational attainment than similarly educated immigrant women, immigrant women appear to be more equally distributed along the two tails of the occupational distribution in Figure 8 than in Figure 6.

\subsubsection{Regression Based Findings on Immigrant Occupational Assimilation}

The descriptive evidence hints at the lower occupational attainment on the part of immigrants relative to natives; yet, there seems to exist some evidence of occupational mobility on the part of immigrants, particularly highly educated migrants. To better isolate the potential impact that time spent in Spain may have on immigrants’ occupational assimilation, we estimate equation (4) separately by gender and for each of the main immigrant groups. The estimation is carried out via an ordered logit, using natives as the reference category. We report the estimated odds ratios for the dummies capturing years elapsed since migration to assess the degree of occupational assimilation as immigrants' residencies lengthen. As in the descriptive analysis, we distinguish according to gender and educational attainment. Table 6a displays the estimated odds ratios for men's (top panel) and women’s (bottom panel) occupational assimilation. Subsequently, Table 6b and Table 6c explore differences in the occupational assimilation rates of men and women with varying educational attainment. 


\section{A) Occupational Assimilation by Gender}

According to the odds ratios in Table 6a, male and female immigrants display a lower occupational attainment than their native counterparts. Specifically, the odds of holding a higher ranked occupation (versus a lower ranked occupation) are 71 percent lower [(0.293-1)=-0.707] for male immigrants and 82 percent lower [0.179-1=-0.82] for female immigrants as compared to natives. Yet, the figures for all immigrants in column 1 also provide evidence of upward occupational mobility as immigrants’ Spanish residencies lengthen. In particular, male and female immigrants with five years of residence enjoy a 47 percent and 120 percent higher likelihood of holding a higher ranked occupation than their native counterparts. While still unable to close the occupational attainment gap with respect to similarly skilled natives, immigrant men and women experience significant upward occupational mobility over the five year period under consideration.

\section{B) Occupational Assimilation by Immigrant Origin}

Are there significant differences in the occupational attainment and mobility of immigrants by origin? Columns 2 through 5 in Table 6a address this question. A few findings are worth emphasizing. First, there are significant differences in the occupational attainment of immigrant men and women relative to similarly skilled natives with the exception of EU15 immigrants. Indeed, immigrant men and women from any of the countries in the EU15 block enjoy alike occupational achievements to those of similarly skilled natives. A second finding worth noting is the overall lack of occupational assimilation among African men and women. In particular, African women endure the lowest occupational attainment of all other immigrant groups upon arrival. 
Finally, it is worth emphasizing the occupational assimilation of other immigrant groups, such as European immigrants from outside the EU15 block and, specifically, Latino immigrants. Both of these immigrant groups display evidence of upward occupational mobility as their residencies lengthen.

\section{C) Occupational Assimilation by Educational Attainment}

As noted earlier, immigrant occupational assimilation may vary according to their human capital. Immigrants endowed with a lower educational attainment may take a longer time to assimilate to their native counterparts occupation-wise than more educated migrants. This appears to be the case when we compare the occupational assimilation of immigrants with primary (Table 6b) to that of immigrants with a secondary education (Table 6c). Non-EU15 and Latino male immigrants with secondary schooling seem to close their occupational attainment gap with respect to similarly skilled natives as their Spanish residencies lengthen. This is also true for Latino women. Yet, occupational assimilation seems to vanish for immigrant men as we compare natives and immigrants with university degrees. The apparent lack of upward occupational assimilation on the part of immigrant men could be simply driven by the limited number of observations in this case. Yet, non-EU15 and Latino women with university degrees assimilate at a faster rate to their native counterparts occupation-wise than their less educated immigrant counterparts.

\subsubsection{Occupational Assimilation or Immigrant Selection via Return Migration?}

Before concluding our discussion on the occupational assimilation of immigrants relative to similarly skilled natives, it is worth discussing the potential role played by return migration. Given the cross-sectional nature of the data, it is possible that the 
upward occupational mobility associated to longer residencies in the host country is the by-product of a positive immigrant selection taking place via return migration (Dustmann, 1999, 2000). Yet, the potential role of return migration in biasing our assimilation estimates is uncertain for a couple of reasons. First, as of today, there is an ongoing debate in the literature as to the sign of the immigrant selection possibly taking place via return migration. On the one hand, it is often argued that successful immigrants are the ones choosing to stay in the host country (e.g. Borjas 1989). Yet, in some instances, successful immigrants return to their home countries upon achieving a savings goal, as in the case with 'target savers' who migrate in order to make enough money to build a home in their home country or to retire (e.g. Berninghaus and Seifert-Vogt 1993). To the extent that both cases of immigrant selectivity may be taking place, various studies have been unable to conclude whether return migration results in a positively or negatively selected sample of host country stayers (Constant and Massey 2003, Hunt 2004). Nonetheless, since immigrants appear to be performing quite well after their arrival, they are unlikely to return to their home countries unless they are 'target savers'. Therefore, we would be, most likely, underestimating immigrant assimilation rates. Furthermore, our focus on relatively recent migrants with up to five years of residence diminishes the role of return migration. Consequently, it is unclear the role played by return migration in the assimilation estimates of recent immigrants in Spain.

\section{Summary and Conclusions}

This paper provides a preliminary analysis of the assimilation of recent immigrant waves to the Spanish labor market in terms of their employment likelihood, occupational attainment and occupational upward mobility as their residencies lengthen. We rely on 
data from the 2001 Population Census and on wage information from the 2002 Earnings Structure Survey. Several conclusions can be withdrawn from the analysis. First, immigrant men and women appear significantly less likely to be employed than similarly skilled natives. The employment gap varies by gender (from 14 percent for men to 7 percent for women) as well as by immigrants' origin. In particular, immigrant men from non-EU15 countries endure the largest employment gap with respect to similar natives, i.e. in the order of 17 percentage points. In contrast, African immigrants are only 10 percentage points less likely to be employed than comparable natives. Among women, recent immigrants from the EU15 countries are 16 percentage points less likely to be employed than similar natives, whereas recently arrived Latino women are only 6 percentage points less likely to be at work than alike natives. Furthermore, immigrants' employment likelihood does not necessarily increase monotonically with years since migration. Instead, immigrant assimilation employment-wise seems greater in the first year following migration. By immigrant origin, the employment gap closes at a faster rate for Latinos and at a slower pace for EU15 immigrants.

Second, the occupational attainment of EU15 immigrants seems on par with the one achieved by similarly skilled natives. However, there exists evidence of an occupational attainment gap between other non-EU15, African, and Latino immigrants and their native counterparts. The data also seem to support the notion of upward occupational mobility and assimilation on the part of non-EU15 and Latino immigrants as their Spanish residencies lengthen. However, we find no clear pattern of occupational assimilation in the case of African immigrants. We also examine differences in the occupational assimilation patterns of immigrants depending on their educational 
attainment. It is not surprising to find that low educated immigrants with lesser human capital experience a slower occupational assimilation process than their counterparts with a secondary education. Yet, possibly due to the limited number of observations available on immigrants with a university degree, we find no evidence of occupational assimilation monotonically increasing with immigrants’ educational attainment beyond secondary schooling except for non-EU15 and Latino immigrant women.

Overall, this study adds to our knowledge of immigrants’ labor market assimilation -an important issue from a social and economic point of view in a country like Spain, where immigration flows have grown at an impressive rate over the past decade. 


\section{References}

Bevelander, P. and HS Nielsen. (2001). “Declining employment success of immigrant males in Sweden: Observed or Unobserved characteristics?”, Journal of Population Economics, 14 (3) , pp: 455-472.

Berninghaus, S. and H.G. Seifert-Vogt. (1993). “The Role of the Target Saving Motive in Guest Worker Migration”, Journal of Economic Dynamics and Control, 17(12):181-205.

Borjas, G. (1985). “Assimilation, Changes in Cohort Quality, and the Earnings of Immigrants”, Journal of Labor Economics, 3: 463-469. . (1986). “The Self-Employment experience of Immigrants”, NBER working paper no. 1942. . (1989). "Immigrants and Emigrant Earnings: A Longitudinal Study”, Economic Inquiry, 27(1): 21-37. • (1995). “Assimilation and Changes in Cohort Quality Revisited: What happened to Immigrant Earnings in the 1980s?” Journal of Labor Economics, 13: $201-245$.

Chiswick, B. (1978). “The effect of Americanization on the Earnings of Foreign-Born Men”, Journal of Political Economy, 86: 897-921.

Constant, A. and D.S. Massey. (2003). “Self-selection, earnings and out-migration: A longitudinal study of immigrants to Germany”, Journal of Population Economics, 16(4): 631-53.

Dustmann, C. (1999), “Temporary Migration, Human Capital and Language Fluency of Migrants”, Scandinavian Journal of Economics, 101, 
Dustmann, C. (2000). “Temporary Migration and Economic Assimilation”, Swedish Economic Policy Review, 7: 213-244.

Hartog, J. and R. Winkelmann (2002). “Comparing migrants to non-migrants: The case of Dutch migration to New Zealand”, Journal of Population Economics,

Hunt, J. (2004). “Are Migrants More Skilled than Non-migrants? Repeat, Return, and Same-Employer Migrants”, Canadian Journal of Economics, 37(4): 830-49.

Longva, P. and O. Raaum. (2003). "Earnings assimilation of immigrants in Norway - A reappraisal”, Journal of Population Economics, 16, pp: 177-193

Wheatly Price S. (1999). “The employment adjustment of male immigrants in England”, Journal of Population Economics, 14(1), pp: 193-220 
Table 1

Descriptive Statistics of the Sample: Means and Standard Deviations

\begin{tabular}{|c|c|c|c|c|c|c|c|c|c|c|c|c|}
\hline & \multicolumn{2}{|c|}{ Natives } & \multicolumn{2}{|c|}{ Immigrants } & \multicolumn{2}{|c|}{ EU15 } & \multicolumn{2}{|c|}{ Non-EU15 } & \multicolumn{2}{|c|}{ Africa } & \multicolumn{2}{|c|}{ Latinos } \\
\hline & Men & Women & Men & Women & Men & Women & Men & Women & Men & Women & Men & Women \\
\hline Age & $\begin{array}{l}38.333 \\
11.814\end{array}$ & $\begin{array}{l}36.282 \\
11.002\end{array}$ & $\begin{array}{c}32.224 \\
8.785\end{array}$ & $\begin{array}{c}32.12 \\
8.92\end{array}$ & $\begin{array}{l}36.817 \\
10.105\end{array}$ & $\begin{array}{c}34.805 \\
9.881\end{array}$ & $\begin{array}{c}32.407 \\
8.570\end{array}$ & $\begin{array}{c}32.149 \\
9.011\end{array}$ & $\begin{array}{c}30.299 \\
7.592\end{array}$ & $\begin{array}{c}30.604 \\
8.554\end{array}$ & $\begin{array}{c}32.191 \\
8.777\end{array}$ & $\begin{array}{c}32.095 \\
8.752\end{array}$ \\
\hline $\begin{array}{l}\text { Head of } \\
\text { Household }\end{array}$ & $\begin{array}{l}0.540 \\
0.498\end{array}$ & $\begin{array}{l}0.365 \\
0.481\end{array}$ & $\begin{array}{l}0.410 \\
0.492\end{array}$ & $\begin{array}{l}0.33 \\
0.47\end{array}$ & $\begin{array}{l}0.677 \\
0.468\end{array}$ & $\begin{array}{l}0.547 \\
0.498\end{array}$ & $\begin{array}{l}0.403 \\
0.491\end{array}$ & $\begin{array}{l}0.326 \\
0.469\end{array}$ & $\begin{array}{l}0.380 \\
0.486\end{array}$ & $\begin{array}{l}0.316 \\
0.465\end{array}$ & $\begin{array}{l}0.363 \\
0.481\end{array}$ & $\begin{array}{l}0.309 \\
0.462\end{array}$ \\
\hline Married & $\begin{array}{l}0.578 \\
0.494\end{array}$ & $\begin{array}{l}0.518 \\
0.500\end{array}$ & $\begin{array}{l}0.468 \\
0.499\end{array}$ & $\begin{array}{l}0.429 \\
0.495\end{array}$ & $\begin{array}{l}0.444 \\
0.497\end{array}$ & $\begin{array}{l}0.369 \\
0.483\end{array}$ & $\begin{array}{l}0.567 \\
0.496\end{array}$ & $\begin{array}{l}0.536 \\
0.499\end{array}$ & $\begin{array}{l}0.397 \\
0.489\end{array}$ & $\begin{array}{l}0.451 \\
0.498\end{array}$ & $\begin{array}{l}0.487 \\
0.500\end{array}$ & $\begin{array}{l}0.401 \\
0.490\end{array}$ \\
\hline $\begin{array}{l}\text { Years since } \\
\text { Entry }\end{array}$ & $\begin{array}{l}38.333 \\
11.814\end{array}$ & $\begin{array}{l}36.282 \\
11.002\end{array}$ & $\begin{array}{l}1.907 \\
1.667\end{array}$ & $\begin{array}{l}1.72 \\
1.47\end{array}$ & $\begin{array}{l}2.498 \\
1.918\end{array}$ & $\begin{array}{l}2.730 \\
1.967\end{array}$ & $\begin{array}{l}1.619 \\
1.458\end{array}$ & $\begin{array}{l}1.713 \\
1.575\end{array}$ & $\begin{array}{l}2.332 \\
1.735\end{array}$ & $\begin{array}{l}2.433 \\
1.785\end{array}$ & $\begin{array}{l}1.506 \\
1.465\end{array}$ & $\begin{array}{l}1.776 \\
1.659\end{array}$ \\
\hline \multicolumn{13}{|c|}{ Education } \\
\hline $\begin{array}{l}\text { Less than } \\
\text { Primary }\end{array}$ & $\begin{array}{l}0.060 \\
0.238\end{array}$ & $\begin{array}{l}0.045 \\
0.206\end{array}$ & $\begin{array}{l}0.149 \\
0.356\end{array}$ & $\begin{array}{l}0.081 \\
0.271\end{array}$ & $\begin{array}{l}0.032 \\
0.175\end{array}$ & $\begin{array}{l}0.027 \\
0.163\end{array}$ & $\begin{array}{l}0.091 \\
0.287\end{array}$ & $\begin{array}{l}0.062 \\
0.241\end{array}$ & $\begin{array}{l}0.344 \\
0.475\end{array}$ & $\begin{array}{l}0.256 \\
0.437\end{array}$ & $\begin{array}{l}0.067 \\
0.250\end{array}$ & $\begin{array}{l}0.063 \\
0.242\end{array}$ \\
\hline Primary & $\begin{array}{l}0.199 \\
0.399\end{array}$ & $\begin{array}{l}0.140 \\
0.347\end{array}$ & $\begin{array}{l}0.209 \\
0.407\end{array}$ & $\begin{array}{l}0.174 \\
0.378\end{array}$ & $\begin{array}{l}0.098 \\
0.297\end{array}$ & $\begin{array}{l}0.074 \\
0.262\end{array}$ & $\begin{array}{l}0.197 \\
0.398\end{array}$ & $\begin{array}{l}0.173 \\
0.378\end{array}$ & $\begin{array}{l}0.292 \\
0.455\end{array}$ & $\begin{array}{l}0.271 \\
0.444\end{array}$ & $\begin{array}{l}0.188 \\
0.391\end{array}$ & $\begin{array}{l}0.172 \\
0.377\end{array}$ \\
\hline Secondary & $\begin{array}{l}0.581 \\
0.493\end{array}$ & $\begin{array}{l}0.559 \\
0.497\end{array}$ & $\begin{array}{l}0.522 \\
0.500\end{array}$ & $\begin{array}{l}0.592 \\
0.492\end{array}$ & $\begin{array}{l}0.572 \\
0.495\end{array}$ & $\begin{array}{l}0.568 \\
0.496\end{array}$ & $\begin{array}{l}0.608 \\
0.488\end{array}$ & $\begin{array}{l}0.594 \\
0.491\end{array}$ & $\begin{array}{l}0.319 \\
0.466\end{array}$ & $\begin{array}{l}0.405 \\
0.491\end{array}$ & $\begin{array}{l}0.616 \\
0.486\end{array}$ & $\begin{array}{l}0.628 \\
0.483\end{array}$ \\
\hline University & $\begin{array}{l}0.160 \\
0.366\end{array}$ & $\begin{array}{l}0.256 \\
0.437\end{array}$ & $\begin{array}{l}0.121 \\
0.326\end{array}$ & $\begin{array}{l}0.153 \\
0.362\end{array}$ & $\begin{array}{l}0.298 \\
0.458\end{array}$ & $\begin{array}{l}0.331 \\
0.471\end{array}$ & $\begin{array}{l}0.105 \\
0.307\end{array}$ & $\begin{array}{l}0.171 \\
0.376\end{array}$ & $\begin{array}{l}0.045 \\
0.208\end{array}$ & $\begin{array}{l}0.068 \\
0.252\end{array}$ & $\begin{array}{l}0.129 \\
0.335\end{array}$ & $\begin{array}{l}0.138 \\
0.345\end{array}$ \\
\hline \multicolumn{13}{|c|}{ Work Status } \\
\hline Employed & $\begin{array}{l}0.892 \\
0.311\end{array}$ & $\begin{array}{l}0.812 \\
0.391\end{array}$ & $\begin{array}{l}0.825 \\
0.380\end{array}$ & $\begin{array}{l}0.806 \\
0.396\end{array}$ & $\begin{array}{l}0.838 \\
0.369\end{array}$ & $\begin{array}{l}0.776 \\
0.417\end{array}$ & $\begin{array}{l}0.825 \\
0.380\end{array}$ & $\begin{array}{l}0.807 \\
0.395\end{array}$ & $\begin{array}{l}0.819 \\
0.385\end{array}$ & $\begin{array}{l}0.747 \\
0.435\end{array}$ & $\begin{array}{l}0.821 \\
0.383\end{array}$ & $\begin{array}{l}0.819 \\
0.385\end{array}$ \\
\hline Unemployed & $\begin{array}{l}0.108 \\
0.311\end{array}$ & $\begin{array}{l}0.188 \\
0.391\end{array}$ & $\begin{array}{l}0.175 \\
0.380\end{array}$ & $\begin{array}{l}0.194 \\
0.396\end{array}$ & $\begin{array}{l}0.162 \\
0.369\end{array}$ & $\begin{array}{l}0.224 \\
0.417\end{array}$ & $\begin{array}{l}0.175 \\
0.380\end{array}$ & $\begin{array}{l}0.193 \\
0.395\end{array}$ & $\begin{array}{l}0.181 \\
0.385\end{array}$ & $\begin{array}{l}0.253 \\
0.435\end{array}$ & $\begin{array}{l}0.179 \\
0.383\end{array}$ & $\begin{array}{l}0.181 \\
0.385\end{array}$ \\
\hline $\mathrm{N}$ & 535192 & 361140 & 16041 & 10950 & 1737 & 1004 & 2383 & 1610 & 4390 & 1043 & 6840 & 6955 \\
\hline
\end{tabular}


Table 2

Probit of the Likelihood of Being Employed of Immigrant Men Relative to Natives Coefficients, (S.E.), and [Marginal Effects]

\begin{tabular}{|c|c|c|c|c|c|}
\hline Years Since Entry & $\begin{array}{c}\text { All } \\
\text { Immigrants }\end{array}$ & EU15 & Non-EU15 & Africa & Latinos \\
\hline Immigrant 0 years & $\begin{array}{c}-0.6131^{* * *} \\
(0.0235) \\
{[-0.139]}\end{array}$ & $\begin{array}{c}-0.5710 * * * \\
(0.0799) \\
{[-0.127]}\end{array}$ & $\begin{array}{c}-0.7108 * * * \\
(0.0596) \\
{[-0.170]}\end{array}$ & $\begin{array}{c}-0.4666 * * * \\
(0.0523) \\
{[-0.098]}\end{array}$ & $\begin{array}{c}-0.6524 * * * \\
(0.0320) \\
{[-0.152]}\end{array}$ \\
\hline Immigrant 1 Year & $\begin{array}{c}0.3121 * * * \\
(0.0338) \\
{[0.040]}\end{array}$ & $\begin{array}{c}0.1650 \\
(0.1196) \\
{[0.023]}\end{array}$ & $\begin{array}{c}0.3121 * * * \\
(0.0841) \\
{[0.039]}\end{array}$ & $\begin{array}{c}0.2093 * * * \\
(0.0739) \\
{[0.028]}\end{array}$ & $\begin{array}{c}0.3836 * * * \\
(0.0471) \\
{[0.046]}\end{array}$ \\
\hline Immigrant 2 Years & $\begin{array}{c}0.4465 * * * \\
(0.0357) \\
{[0.052]}\end{array}$ & $\begin{array}{c}0.2167^{*} \\
(0.1161) \\
{[0.029]}\end{array}$ & $\begin{array}{c}0.3605 * * * \\
(0.0912) \\
{[0.044]}\end{array}$ & $\begin{array}{c}0.3389 * * * \\
(0.0702) \\
{[0.042]}\end{array}$ & $\begin{array}{c}0.5453 * * * \\
(0.0543) \\
{[0.059]}\end{array}$ \\
\hline Immigrant 3 Years & $\begin{array}{c}0.5566 * * * \\
(0.0444) \\
{[0.060]}\end{array}$ & $\begin{array}{c}0.3228 * * * \\
(0.1278) \\
{[0.041]}\end{array}$ & $\begin{array}{c}0.8279 * * * \\
(0.1333) \\
{[0.072]}\end{array}$ & $\begin{array}{c}0.4045^{* * *} \\
(0.0791) \\
{[0.048]}\end{array}$ & $\begin{array}{c}0.6446 * * * \\
(0.0797) \\
{[0.064]}\end{array}$ \\
\hline Immigrant 4 Years & $\begin{array}{c}0.4780 * * * \\
(0.0545) \\
{[0.055]}\end{array}$ & $\begin{array}{c}0.1905 \\
(0.1330) \\
{[0.026]}\end{array}$ & $\begin{array}{c}0.6086 * * * \\
(0.1819) \\
{[0.062]}\end{array}$ & $\begin{array}{c}0.4881 * * * \\
(0.0977) \\
{[0.054]}\end{array}$ & $\begin{array}{c}0.4637 * * * \\
(0.0972) \\
{[0.053]}\end{array}$ \\
\hline Immigrant 5 Years & $\begin{array}{c}0.4720 * * * \\
(0.0612) \\
{[0.054]}\end{array}$ & $\begin{array}{c}0.4773 * * * \\
(0.1575) \\
{[0.053]}\end{array}$ & $\begin{array}{c}1.2429 * * * \\
(0.2828) \\
{[0.082]}\end{array}$ & $\begin{array}{c}0.3173 * * * \\
(0.1004) \\
{[0.040]}\end{array}$ & $\begin{array}{c}0.4356 * * * \\
(0.1184) \\
{[0.051]}\end{array}$ \\
\hline $\begin{array}{l}\text { No. of Observations } \\
\text { Wald Chi2 (64) } \\
\text { Prob > Chi2 }\end{array}$ & $\begin{array}{c}551233 \\
35040.86 \\
0.0000\end{array}$ & $\begin{array}{c}536929 \\
34142.13 \\
0.0000\end{array}$ & $\begin{array}{c}537575 \\
34166.29 \\
0.0000\end{array}$ & $\begin{array}{c}539582 \\
34248.19 \\
0.0000\end{array}$ & $\begin{array}{c}539032 \\
34576.90 \\
0.0000\end{array}$ \\
\hline
\end{tabular}

Notes: The regressions include controls for age, household head status, marital status, educational attainment, province of residence, and a constant term. An immigrant with less than 1 year of residence in Spain is used as the category of reference. ${ }^{* * *}$ Signifies statistically different from zero at the $1 \%$ level or better, **at the $5 \%$ level or better and *at the $10 \%$ level or better. 
Table 3

Probit of the Likelihood of Being Employed of Immigrant Women Relative to Natives Coefficients, (S.E.), and [Marginal Effects]

\begin{tabular}{|c|c|c|c|c|c|}
\hline Years Since Entry & $\begin{array}{c}\text { All } \\
\text { Immigrants }\end{array}$ & EU15 & Non-EU15 & Africa & Latinos \\
\hline Immigrant 0 years & $\begin{array}{c}-0.2500 * * * \\
(0.0274) \\
{[-0.069]}\end{array}$ & $\begin{array}{c}-0.5165 * * * \\
(0.1036) \\
{[-0.159]}\end{array}$ & $\begin{array}{c}-0.2632 * * * \\
(0.0689) \\
{[-0.074]}\end{array}$ & $\begin{array}{c}-0.3911^{* * *} \\
(0.0956) \\
{[-0.115]}\end{array}$ & $\begin{array}{c}-0.2020 * * * \\
(0.0333) \\
{[-0.055]}\end{array}$ \\
\hline Immigrant 1 Year & $\begin{array}{c}0.3233 * * * \\
(0.0393) \\
{[0.069]}\end{array}$ & $\begin{array}{c}0.1935 \\
(0.1496) \\
{[0.044]}\end{array}$ & $\begin{array}{c}0.2105^{* *} \\
(0.0985) \\
{[0.047]}\end{array}$ & $\begin{array}{c}0.3978 * * * \\
(0.1409) \\
{[0.081]}\end{array}$ & $\begin{array}{c}0.3570 * * * \\
(0.0479) \\
{[0.074]}\end{array}$ \\
\hline Immigrant 2 Years & $\begin{array}{c}0.3289 * * * \\
(0.0422) \\
{[0.070]}\end{array}$ & $\begin{array}{c}0.3584 * * \\
(0.1490) \\
{[0.074]}\end{array}$ & $\begin{array}{c}0.3484 * * * \\
(0.1065) \\
{[0.073]}\end{array}$ & $\begin{array}{c}0.2454^{*} \\
(0.1302) \\
{[0.054]}\end{array}$ & $\begin{array}{c}0.3613^{* * *} \\
(0.0539) \\
{[0.075]}\end{array}$ \\
\hline Immigrant 3 Years & $\begin{array}{c}0.2882 * * * \\
(0.0496) \\
{[0.062]}\end{array}$ & $\begin{array}{c}0.0976 \\
(0.1496) \\
{[0.023]}\end{array}$ & $\begin{array}{c}0.2354^{*} \\
(0.1295) \\
{[0.052]}\end{array}$ & $\begin{array}{c}0.4374 * * * \\
(0.1429) \\
{[0.087]}\end{array}$ & $\begin{array}{c}0.3236 * * * \\
(0.0664) \\
{[0.068]}\end{array}$ \\
\hline Immigrant 4 Years & $\begin{array}{c}0.2490 * * * \\
(0.0590) \\
{[0.055]}\end{array}$ & $\begin{array}{c}0.3846 * * \\
(0.1683) \\
{[0.079]}\end{array}$ & $\begin{array}{c}0.3314 * * \\
(0.1713) \\
{[0.070]}\end{array}$ & $\begin{array}{c}0.4038 * * * \\
(0.1633) \\
{[0.082]}\end{array}$ & $\begin{array}{c}0.2363 * * * \\
(0.0798) \\
{[0.052]}\end{array}$ \\
\hline Immigrant 5 Years & $\begin{array}{c}0.4109 * * * \\
(0.0687) \\
{[0.083]}\end{array}$ & $\begin{array}{c}0.5843 * * * \\
(0.1758) \\
{[0.107]}\end{array}$ & $\begin{array}{c}0.5903 * * \\
(0.2499) \\
{[0.107]}\end{array}$ & $\begin{array}{c}0.2385 \\
(0.1828) \\
{[0.053]}\end{array}$ & $\begin{array}{c}0.4510^{* * *} \\
(0.0946) \\
{[0.089]}\end{array}$ \\
\hline $\begin{array}{l}\text { No. of Observations } \\
\text { Wald Chi2 } \\
\text { Prob > Chi } 2\end{array}$ & $\begin{array}{c}372090 \\
26126.20 \\
0.0000\end{array}$ & $\begin{array}{c}362144 \\
26085.69 \\
0.0000\end{array}$ & $\begin{array}{c}362750 \\
26043.00 \\
0.0000\end{array}$ & $\begin{array}{c}362183 \\
26082.89 \\
0.0000\end{array}$ & $\begin{array}{c}368095 \\
26012.33 \\
0.0000\end{array}$ \\
\hline
\end{tabular}

Notes: The regressions include controls for age, household head status, marital status, educational attainment, province of residence, and a constant term. An immigrant with less than 1 year of residence in Spain is used as the category of reference. $* * *$ Signifies statistically different from zero at the $1 \%$ level or better, **at the $5 \%$ level or better and *at the $10 \%$ level or better. 
Table 4a

Differences in the Predicted Employment Probabilities of Immigrants Relative to Natives By Region of Origin and By Years since Entry - MEN

\begin{tabular}{|c|c|c|c|c|}
\hline Comparison Groups & $\begin{array}{c}\text { Predicted } \\
\text { Probability } \\
\text { (1) } \\
\end{array}$ & $\begin{array}{c}\text { Predicted } \\
\text { Probability } \\
(2) \\
\end{array}$ & $\begin{array}{c}\text { Diff. Native- } \\
\text { Immigrant } \\
\text { (1) } \\
\end{array}$ & $\begin{array}{c}\text { Diff. Native- } \\
\text { Immigrant } \\
(2) \\
\end{array}$ \\
\hline Natives & 0.891 & 0.891 & - & \\
\hline Immigrants 0 year & 0.723 & 0.755 & $0.168^{* * *}$ & $0.142^{* * *}$ \\
\hline Immigrants 1 year & 0.826 & 0.852 & $0.064^{* * *}$ & $0.039^{* * *}$ \\
\hline Immigrants 2 years & 0.851 & 0.878 & $0.039^{* * *}$ & $0.013^{* * *}$ \\
\hline Immigrants 3 years & 0.872 & 0.896 & $0.018^{* * *}$ & $-0.069^{* * *}$ \\
\hline Immigrants 4 years & 0.860 & 0.883 & $0.031^{* * *}$ & 0.008 \\
\hline Immigrants 5 years & 0.861 & 0.881 & $0.029^{* * *}$ & 0.01 \\
\hline EU15 Immig. 0 year & 0.791 & 0.770 & $0.100^{* * *}$ & $0.121^{* * *}$ \\
\hline EU15 Immig. 1 year & 0.828 & 0.806 & $0.062^{* * *}$ & $0.085^{* * *}$ \\
\hline EU15 Immig. 2 yrs & 0.838 & 0.815 & $0.053^{* * *}$ & $0.076^{* * *}$ \\
\hline EU15 Immig. 3 yrs & 0.863 & 0.849 & $0.028^{* * *}$ & $0.042^{* * *}$ \\
\hline EU15 Immig. 4 yrs & 0.832 & 0.815 & $0.059^{* * *}$ & $0.076^{* * *}$ \\
\hline EU15 Immig. 5 yrs & 0.891 & 0.875 & 0.002 & $0.016^{* * *}$ \\
\hline Non EU15 Immig. 0 yr & 0.708 & 0.748 & $0.183^{* * *}$ & $0.143^{* * *}$ \\
\hline Non EU15 Immig. 1 yrs & 0.827 & 0.844 & $0.064^{* * *}$ & $0.047^{* * *}$ \\
\hline Non EU15 Immig. 2 yrs & 0.839 & 0.859 & $0.052^{* * *}$ & $0.032^{* * *}$ \\
\hline Non EU15 Immig. 3 yrs & 0.917 & 0.930 & $-0.026^{* * *}$ & $-0.039^{* * *}$ \\
\hline Non EU15 Immig. 4 yrs & 0.893 & 0.903 & -0.002 & $-0.012^{* * *}$ \\
\hline Non EU15 Immig. 5 yrs & 0.957 & 0.961 & $-0.065^{* * *}$ & $-0.07^{* * *}$ \\
\hline African Immig. $0 \mathrm{yr}$ & 0.724 & 0.797 & $0.167^{* * *}$ & $0.094^{* * *}$ \\
\hline African Immig. 1 yr & 0.789 & 0.866 & $0.102^{* * *}$ & $0.025^{* * *}$ \\
\hline African Immig. 2 yr & 0.826 & 0.879 & $0.065^{* * *}$ & $0.012^{* * *}$ \\
\hline African Immig. 3 yr & 0.845 & 0.895 & $0.045^{* * *}$ & -0.0004 \\
\hline African Immig. 4 yr & 0.862 & 0.906 & $0.029^{* * *}$ & $-0.015^{* * *}$ \\
\hline African Immig. $5 \mathrm{yr}$ & 0.841 & 0.885 & $0.049^{* * *}$ & 0.006 \\
\hline Latino Immig. $0 \mathrm{yr}$ & 0.711 & 0.732 & $0.180^{* * *}$ & $0.159^{* * *}$ \\
\hline Latino Immig. $1 \mathrm{yr}$ & 0.840 & 0.855 & $0.051^{* * *}$ & $0.036^{* * *}$ \\
\hline Latino Immig. 2 yr & 0.873 & 0.884 & $0.018^{* * *}$ & 0.007 \\
\hline Latino Immig. $3 \mathrm{yr}$ & 0.899 & 0.898 & 0.002 & -0.007 \\
\hline Latino Immig. $4 \mathrm{yr}$ & 0.864 & 0.869 & $0.027^{* * *}$ & $0.022^{* * *}$ \\
\hline Latino Immig. $5 \mathrm{yr}$ & 0.857 & 0.857 & $0.034^{* * *}$ & $0.034^{* * *}$ \\
\hline
\end{tabular}

Notes: *** Signifies statistically different from zero at the $1 \%$ level or better, **at the $5 \%$ level or better and *at the $10 \%$ level or better. The predicted employment probability (1) refers to the predicted employment probability of a representative individual of each group. The predicted employment probability (2) is computed in all cases for a representative individual of the sample, only being different in their origin and (for immigrants) years since residence. 
Table 4b

Differences in the Predicted Employment Probabilities of Immigrants Relative to Natives By Region of Origin and By Years since Entry - WOMEN

\begin{tabular}{|c|c|c|c|c|}
\hline Comparison Groups & $\begin{array}{c}\text { Predicted } \\
\text { Probability } \\
\text { (1) } \\
\end{array}$ & $\begin{array}{c}\text { Predicted } \\
\text { Probability } \\
(2) \\
\end{array}$ & $\begin{array}{c}\text { Diff. Native- } \\
\text { Immigrant } \\
\text { (1) }\end{array}$ & $\begin{array}{c}\text { Diff. Native- } \\
\text { Immigrant } \\
(2)\end{array}$ \\
\hline Natives & 0.812 & 0.831 & - & \\
\hline Immigrants 0 year & 0.720 & 0.831 & $0.091^{* * *}$ & 0 \\
\hline Immigrants 1 year & 0.823 & 0.899 & $-0.010^{* * *}$ & $-0.068^{* * *}$ \\
\hline Immigrants 2 years & 0.829 & 0.900 & $-0.017^{* * *}$ & $-0.069^{* * *}$ \\
\hline Immigrants 3 years & 0.824 & 0.893 & $-0.012^{* * *}$ & $-0.062^{* * *}$ \\
\hline Immigrants 4 years & 0.815 & 0.886 & -0.003 & $-0.055^{* * *}$ \\
\hline Immigrants 5 years & 0.862 & 0.914 & $-0.050^{* * *}$ & $-0.083^{* * *}$ \\
\hline EU15 Immig. 0 year & 0.685 & 0.832 & $0.127^{* * *}$ & -0.001 \\
\hline EU15 Immig. 1 year & 0.761 & 0.876 & $0.050^{* * *}$ & $-0.045^{* * *}$ \\
\hline EU15 Immig. 2 yrs & 0.805 & 0.906 & 0.007 & $-0.075^{* * *}$ \\
\hline EU15 Immig. 3 yrs & 0.748 & 0.855 & $0.063^{* * *}$ & $-0.024^{* * *}$ \\
\hline EU15 Immig. 4 yrs & 0.818 & 0.910 & -0.006 & $-0.079^{* * *}$ \\
\hline EU15 Immig. 5 yrs & 0.867 & 0.939 & $-0.055^{* * *}$ & $-0.108^{* * *}$ \\
\hline Non EU15 Immig. 0 yr & 0.720 & 0.832 & $0.091^{* * *}$ & -0.001 \\
\hline Non EU15 Immig. 1 yrs & 0.804 & 0.879 & 0.007 & $-0.048^{* * *}$ \\
\hline Non EU15 Immig. 2 yrs & 0.847 & 0.904 & $-0.031^{* * *}$ & $-0.073^{* * *}$ \\
\hline Non EU15 Immig. 3 yrs & 0.810 & 0.884 & 0.001 & $-0.053^{* * *}$ \\
\hline Non EU15 Immig. 4 yrs & 0.832 & 0.902 & $-0.020^{* *}$ & $-0.071^{* * *}$ \\
\hline Non EU15 Immig. 5 yrs & 0.887 & 0.939 & $-0.075^{* * *}$ & $-0.108^{* * *}$ \\
\hline African Immig. $0 \mathrm{yr}$ & 0.644 & 0.831 & $0.167^{* * *}$ & 0 \\
\hline African Immig. 1 yr & 0.812 & 0.913 & $0.045^{* * *}$ & $-0.082^{* * *}$ \\
\hline African Immig. 2 yr & 0.726 & 0.886 & $0.085^{* * *}$ & $-0.055^{* * *}$ \\
\hline African Immig. 3 yr & 0.789 & 0.919 & $0.022^{* * *}$ & $-0.088^{* * *}$ \\
\hline African Immig. 4 yr & 0.764 & 0.914 & $0.047^{* * *}$ & $-0.083^{* * *}$ \\
\hline African Immig. $5 \mathrm{yr}$ & 0.757 & 0.885 & $0.054^{* * *}$ & $-0.054^{* * *}$ \\
\hline Latino Immig. $0 \mathrm{yr}$ & 0.731 & 0.832 & $0.080^{* * *}$ & -0.001 \\
\hline Latino Immig. $1 \mathrm{yr}$ & 0.839 & 0.903 & $-0.026^{* * *}$ & $-0.072^{* * *}$ \\
\hline Latino Immig. 2 yr & 0.847 & 0.907 & $-0.034^{* * *}$ & $-0.076^{* * *}$ \\
\hline Latino Immig. $3 \mathrm{yr}$ & 0.845 & 0.900 & $-0.033^{* * *}$ & $-0.069^{* * *}$ \\
\hline Latino Immig. $4 \mathrm{yr}$ & 0.827 & 0.884 & $-0.015^{* * *}$ & $-0.053^{* * *}$ \\
\hline Latino Immig. $5 \mathrm{yr}$ & 0.812 & 0.921 & $-0.067^{* * *}$ & $-0.09^{* * *}$ \\
\hline
\end{tabular}

Notes: *** Signifies statistically different from zero at the $1 \%$ level or better, **at the $5 \%$ level or better and *at the $10 \%$ level or better. The predicted employment probability (1) refers to the predicted employment probability of a representative individual of each group. The predicted employment probability (2) is computed in all cases for a representative individual of the sample, only being different in their origin and (for immigrants) years since residence. 
Table 4c

Employment Assimilation by Immigrant Origin

\begin{tabular}{lcc}
\hline Immigrant Groups & Men & Women \\
\hline All Immigrants & 0.14 & 0.14 \\
EU15 Immigrants & 0.10 & 0.18 \\
Non-EU15 Immigrants & 0.25 & 0.16 \\
African Immigrants & 0.12 & 0.11 \\
Latino Immigrants & 0.15 & 0.14 \\
& & \\
\hline
\end{tabular}

Notes: Assimilation is measured as: $\hat{P}_{I, 5 y r s}-\hat{P}_{I, 0 y r s}=\left(\hat{P}_{N}-\hat{P}_{I, 0 y r s}\right)-\left(\hat{P}_{N}-\hat{P}_{I, 5 y r s}\right)$ 
Table 5

Average Occupational Rank by Immigrant Origin and Years of Residence

\begin{tabular}{|c|c|c|c|c|c|c|}
\hline \multirow{2}{*}{ Groups } & \multicolumn{3}{|c|}{ Men (Rank varies from 1 to 22) } & \multicolumn{3}{|c|}{ Women (Rank varies from 1 to 17) } \\
\hline & Mean & S.D. & $\mathbf{N}$ & Mean & S.D. & $\mathbf{N}$ \\
\hline Natives & 12.9 & 5.95 & 472,817 & 8.9 & 5.1 & 292568 \\
\hline Immigrants 0 year & 8.5 & 5.9 & 2783 & 4.4 & 4.6 & 1927 \\
\hline Immigrants 1 year & 8.4 & 5.7 & 3510 & 4.4 & 4.6 & 2446 \\
\hline Immigrants 2 years & 8.8 & 5.8 & 3215 & 4.7 & 4.8 & 1944 \\
\hline Immigrants 3 years & 9.1 & 5.9 & 1882 & 5.3 & 4.9 & 1194 \\
\hline Immigrants 4 years & 9.4 & 6.4 & 1044 & 5.6 & 5.2 & 695 \\
\hline Immigrants 5 years & 9.8 & 6.4 & 764 & 6.2 & 5.4 & 604 \\
\hline EU15 Immig. 0 year & 14.0 & 6.7 & 294 & 9.5 & 5.2 & 130 \\
\hline EU15 Immig. 1 year & 13.8 & 6.7 & 261 & 9.5 & 5.2 & 135 \\
\hline EU15 Immig. 2 yrs & 14.2 & 6.4 & 299 & 9.3 & 5.4 & 158 \\
\hline EU15 Immig. 3 yrs & 13.5 & 6.5 & 257 & 9.8 & 5.2 & 128 \\
\hline EU15 Immig. 4 yrs & 13.9 & 6.4 & 181 & 10.1 & 5.4 & 109 \\
\hline EU15 Immig. 5 yrs & 13.8 & 6.6 & 161 & 10.5 & 5.1 & 121 \\
\hline Non EU15 Immig. 0 yr & 7.4 & 5.2 & 423 & 4.0 & 4.1 & 305 \\
\hline Non EU15 Immig. 1 yrs & 7.5 & 4.9 & 624 & 4.5 & 4.5 & 369 \\
\hline Non EU15 Immig. 2 yrs & 8.8 & 5.3 & 479 & 4.6 & 4.6 & 327 \\
\hline Non EU15 Immig. 3 yrs & 8.9 & 5.6 & 262 & 4.8 & 4.7 & 156 \\
\hline Non EU15 Immig. 4 yrs & 9.5 & 5.7 & 111 & 5.7 & 5.1 & 80 \\
\hline Non EU15 Immig. 5 yrs & 9.7 & 6.7 & 65 & 5.7 & 4.9 & 51 \\
\hline African Immig. 0 yr & 6.6 & 5.3 & 571 & 4.7 & 3.7 & 121 \\
\hline African Immig. 1 yr & 6.6 & 5.1 & 681 & 4.5 & 4.1 & 144 \\
\hline African Immig. 2 yr & 7.2 & 5.2 & 970 & 4.5 & 4.1 & 191 \\
\hline African Immig. 3 yr & 6.8 & 4.8 & 663 & 4.3 & 3.8 & 165 \\
\hline African Immig. 4 yr & 6.6 & 5.3 & 396 & 3.7 & 3.7 & 88 \\
\hline African Immig. 5 yr & 7.3 & 5.2 & 300 & 4.5 & 4.1 & 63 \\
\hline Latino Immig. 0 yr & 8.4 & 5.5 & 1403 & 3.9 & 4.4 & 1340 \\
\hline Latino Immig. 1 yr & 8.6 & 5.5 & 1849 & 4.0 & 4.3 & 1750 \\
\hline Latino Immig. 2 yr & 8.7 & 5.5 & 1310 & 4.3 & 4.6 & 1201 \\
\hline Latino Immig. 3 yr & 9.4 & 5.8 & 567 & 4.8 & 4.8 & 676 \\
\hline Latino Immig. 4 yr & 10.2 & 6.2 & 297 & 4.7 & 4.7 & 384 \\
\hline Latino Immig. 5 yr & 10.6 & 6.0 & 184 & 5.4 & 5.1 & 339 \\
\hline
\end{tabular}


Table 6a

Ordered Logit Estimates - Odd Ratios

Dependent Variable: Occupational Ranking

All Educational Levels

\begin{tabular}{|c|c|c|c|c|c|}
\hline \multirow{2}{*}{$\begin{array}{l}\text { Comparison Group } \\
\text { (Control Group: Natives) }\end{array}$} & \multicolumn{5}{|c|}{ PANEL A: MEN (22 occupational categories) } \\
\hline & $\begin{array}{c}\text { All } \\
\text { Immigrants }\end{array}$ & EU15 & Non-EU15 & Africa & Latino \\
\hline Immigrants 0 year residence & $\begin{array}{l}0.293^{* * *} \\
(0.010)\end{array}$ & $\begin{array}{c}1.113 \\
(0.139)\end{array}$ & $\begin{array}{l}0.216^{* * *} \\
(0.020)\end{array}$ & $\begin{array}{l}0.239^{* * *} \\
(0.017)\end{array}$ & $\begin{array}{l}0.261^{* * *} \\
(0.013)\end{array}$ \\
\hline Immigrants 1 year residence & $\begin{array}{c}0.952 \\
(0.047)\end{array}$ & $\begin{array}{c}0.867 \\
(0.160)\end{array}$ & $\begin{array}{c}0.907 \\
(0.108)\end{array}$ & $\begin{array}{c}1.054 \\
(0.107)\end{array}$ & $\begin{array}{c}1.046 \\
(0.070)\end{array}$ \\
\hline Immigrants 2 years residence & $\begin{array}{l}1.111^{* * *} \\
(0.056)\end{array}$ & $\begin{array}{c}0.986 \\
(0.164)\end{array}$ & $\begin{array}{l}1.322^{* * *} \\
(0.167)\end{array}$ & $\begin{array}{l}1.247^{* * *} \\
(0.120)\end{array}$ & $\begin{array}{c}1.038 \\
(0.077)\end{array}$ \\
\hline Immigrants 3 years residence & $\begin{array}{l}1.261^{* * *} \\
(0.073)\end{array}$ & $\begin{array}{c}0.873 \\
(0.146)\end{array}$ & $\begin{array}{l}0.418^{* * *} \\
(0.218)\end{array}$ & $\begin{array}{c}1.102 \\
(0.112)\end{array}$ & $\begin{array}{l}1.478^{* * *} \\
(0.139)\end{array}$ \\
\hline Immigrants 4 years residence & $\begin{array}{l}1.273^{* * *} \\
(0.093)\end{array}$ & $\begin{array}{l}1.035 \\
(0.203)\end{array}$ & $\begin{array}{l}1.720^{* * *} \\
(0.332)\end{array}$ & $\begin{array}{c}0.988 \\
(0.117)\end{array}$ & $\begin{array}{l}1.312^{* * *} \\
(0.175)\end{array}$ \\
\hline Immigrants 5 years residence & $\begin{array}{l}1.471^{* * *} \\
(0.119)\end{array}$ & $\begin{array}{c}0.947 \\
(0.198)\end{array}$ & $\begin{array}{l}1.853^{* * *} \\
(0.537)\end{array}$ & $\begin{array}{c}1.216 \\
(0.162)\end{array}$ & $\begin{array}{l}1.601^{* * *} \\
(0.230)\end{array}$ \\
\hline $\begin{array}{l}\text { N. of observations } \\
\text { (natives }=477,154 \text { ) }\end{array}$ & 13,214 & 1,458 & 1,966 & 3,585 & 5,615 \\
\hline \multirow[b]{2}{*}{$\begin{array}{l}\text { Comparison Group } \\
\text { (Control Group: Natives) }\end{array}$} & \multicolumn{5}{|c|}{ PANEL B : WOMEN (17 occupational categories) } \\
\hline & $\begin{array}{c}\text { All } \\
\text { Immigrants }\end{array}$ & EU15 & Non-EU15 & Africa & Latino \\
\hline Immigrants 0 year residence & $\begin{array}{l}0.179^{* * *} \\
(0.009)\end{array}$ & $\begin{array}{c}1.023 \\
(0.158)\end{array}$ & $\begin{array}{l}0.175^{* * *} \\
(0.020)\end{array}$ & $\begin{array}{l}0.396^{* * *} \\
(0.067)\end{array}$ & $\begin{array}{c}0.132^{* * *} \\
(0.009)\end{array}$ \\
\hline Immigrants 1 year residence & $\begin{array}{c}1.000 \\
(0.072)\end{array}$ & $\begin{array}{c}1.014 \\
(0.228)\end{array}$ & $\begin{array}{c}1.030 \\
(0.175)\end{array}$ & $\begin{array}{c}0.938 \\
(0.233)\end{array}$ & $\begin{array}{c}1.044 \\
(0.093)\end{array}$ \\
\hline Immigrants 2 years residence & $\begin{array}{l}1.192^{* * *} \\
(0.091)\end{array}$ & $\begin{array}{c}1.047 \\
(0.227)\end{array}$ & $\begin{array}{c}0.901 \\
(0.167)\end{array}$ & $\begin{array}{c}1.116 \\
(0.252)\end{array}$ & $\begin{array}{l}1.184^{* *} \\
(0.115)\end{array}$ \\
\hline Immigrants 3 years residence & $\begin{array}{l}1.640^{* * *} \\
(0.138)\end{array}$ & $\begin{array}{c}1.055 \\
(0.235)\end{array}$ & $\begin{array}{c}1.343 \\
(0.281)\end{array}$ & $\begin{array}{c}1.192 \\
(0.263)\end{array}$ & $\begin{array}{l}1.521^{\text {*** }} \\
(0.175)\end{array}$ \\
\hline Immigrants 4 years residence & $\begin{array}{l}1.691^{* * * *} \\
(0.171)\end{array}$ & $\begin{array}{c}1.324 \\
(0.329)\end{array}$ & $\begin{array}{l}1.912^{* * *} \\
(0.535)\end{array}$ & $\begin{array}{c}0.683 \\
(0.194)\end{array}$ & $\begin{array}{l}1.431^{* * *} \\
(0.192)\end{array}$ \\
\hline Immigrants 5 years residence & $\begin{array}{l}2.196^{* * *} \\
(0.232)\end{array}$ & $\begin{array}{l}1.543^{* *} \\
(0.385)\end{array}$ & $\begin{array}{l}2.059^{* * *} \\
(0.702)\end{array}$ & $\begin{array}{c}1.184 \\
(0.354)\end{array}$ & $\begin{array}{l}1.799^{* * *} \\
(0.255)\end{array}$ \\
\hline $\begin{array}{l}\text { N. of observations } \\
\text { (natives }=293,233 \text { ) }\end{array}$ & 8,815 & 781 & 1,290 & 773 & 5,692 \\
\hline
\end{tabular}

Notes: *** Signifies statistically different from zero at the $1 \%$ level or better, **at the $5 \%$ level or better and *at the $10 \%$ level or better. The values for the dependent variable range from 1 to 22 in the case of men and from 1 to 17 in the case of women. The smallest (highest) value is taken by that occupation or group of occupations with the lowest (higher) average gross hourly earnings as of 2002 (Source: Earnings Structure Survey, EES-02). Estimations also include age, education, indicator for marital status and region dummies (52 province dummies). Standard errors are computed using White’s variance estimator. 
Table 6b

Ordered Logit Estimates - Odd Ratios

Dependent Variable: Occupational Ranking

Primary Educational Attainment

\begin{tabular}{|c|c|c|c|c|c|}
\hline \multirow{2}{*}{$\begin{array}{l}\text { Comparison Group } \\
\text { (Control Group: Natives) }\end{array}$} & \multicolumn{5}{|c|}{ PANEL A: MEN (22 occupational categories) } \\
\hline & $\begin{array}{c}\text { All } \\
\text { Immigrants }\end{array}$ & EU15 & Non-EU15 & Africa & Latino \\
\hline Immigrants 0 year residence & $\begin{array}{l}0.281^{* * *} \\
(0.016)\end{array}$ & $\begin{array}{c}0.725 \\
(0.227)\end{array}$ & $\begin{array}{l}0.307^{* * *} \\
(0.047)\end{array}$ & $\begin{array}{l}0.203^{* * *} \\
(0.017)\end{array}$ & $\begin{array}{l}0.324^{* * *} \\
(0.030)\end{array}$ \\
\hline Immigrants 1 year residence & $\begin{array}{l}1.142^{* *} \\
(0.086)\end{array}$ & $\begin{array}{c}0.769 \\
(0.347)\end{array}$ & $\begin{array}{c}1.076 \\
(0.218)\end{array}$ & $\begin{array}{l}1.262^{* * *} \\
(0.144)\end{array}$ & $\begin{array}{c}1.105 \\
(0.137)\end{array}$ \\
\hline Immigrants 2 years residence & $\begin{array}{l}1.202^{* * *} \\
(0.094)\end{array}$ & $\begin{array}{c}1.621 \\
(0.708)\end{array}$ & $\begin{array}{c}1.095 \\
(0.254)\end{array}$ & $\begin{array}{l}1.444^{* * *} \\
(0.160)\end{array}$ & $\begin{array}{c}1.030 \\
(0.139)\end{array}$ \\
\hline Immigrants 3 years residence & $\begin{array}{l}1.271^{* * *} \\
(0.111)\end{array}$ & $\begin{array}{c}1.968 \\
(0.909)\end{array}$ & $\begin{array}{c}1.301 \\
(0.327)\end{array}$ & $\begin{array}{l}1.253^{* *} \\
(0.148)\end{array}$ & $\begin{array}{l}1.591^{* * *} \\
(0.272)\end{array}$ \\
\hline Immigrants 4 years residence & $\begin{array}{c}1.058 \\
(0.113)\end{array}$ & $\begin{array}{c}1.398 \\
(0.628)\end{array}$ & $\begin{array}{c}1.011 \\
(0.304)\end{array}$ & $\begin{array}{c}1.094 \\
(0.146)\end{array}$ & $\begin{array}{c}1.259 \\
(0.344)\end{array}$ \\
\hline Immigrants 5 years residence & $\begin{array}{l}1.135^{* * *} \\
(0.145)\end{array}$ & $\begin{array}{c}1.446 \\
(0.768)\end{array}$ & $\begin{array}{c}0.719 \\
(0.340)\end{array}$ & $\begin{array}{c}1.204 \\
(0.195)\end{array}$ & $\begin{array}{c}1.285 \\
(0.319)\end{array}$ \\
\hline $\begin{array}{l}\text { N. of observations } \\
\text { (natives=117,347) }\end{array}$ & 4,721 & 180 & 309 & 2,297 & 1,454 \\
\hline \multirow[b]{2}{*}{$\begin{array}{l}\text { Comparison Group } \\
\text { (Control Group: Natives) }\end{array}$} & \multicolumn{5}{|c|}{ PANEL B : WOMEN (17 occupational categories) } \\
\hline & $\begin{array}{c}\text { All } \\
\text { Immigrants }\end{array}$ & EU15 & Non-EU15 & Africa & Latino \\
\hline Immigrants 0 year residence & $\begin{array}{l}0.312^{* * *} \\
(0.027)\end{array}$ & $\begin{array}{c}0.396 \\
(0.447)\end{array}$ & $\begin{array}{l}0.261^{* * *} \\
(0.046)\end{array}$ & $\begin{array}{c}0.707^{*} \\
(0.164)\end{array}$ & $\begin{array}{c}0.282^{* * *} \\
(0.031)\end{array}$ \\
\hline Immigrants 1 year residence & $\begin{array}{c}1.030 \\
(0.118)\end{array}$ & $\begin{array}{c}1.330 \\
(1.573)\end{array}$ & $\begin{array}{l}1.612^{* *} \\
(0.435)\end{array}$ & $\begin{array}{c}0.729 \\
(0.212)\end{array}$ & $\begin{array}{c}0.917 \\
(0.133)\end{array}$ \\
\hline Immigrants 2 years residence & $\begin{array}{l}1.135 \\
(0.134)\end{array}$ & $\begin{array}{c}2.792 \\
(3.281)\end{array}$ & $\begin{array}{c}1.321 \\
(0.378)\end{array}$ & $\begin{array}{c}0.730 \\
(0.205)\end{array}$ & $\begin{array}{c}0.939 \\
(0.144)\end{array}$ \\
\hline Immigrants 3 years residence & $\begin{array}{l}1.479^{* * *} \\
(0.193)\end{array}$ & $\begin{array}{c}1.865 \\
(2.262)\end{array}$ & $\begin{array}{l}1.645^{* *} \\
(0.497)\end{array}$ & $\begin{array}{c}0.818 \\
(0.223)\end{array}$ & $\begin{array}{c}1.348 \\
(0.271)\end{array}$ \\
\hline Immigrants 4 years residence & $\begin{array}{c}1.145 \\
(0.182)\end{array}$ & $\begin{array}{c}3.158 \\
(3.773)\end{array}$ & $\begin{array}{l}1.892^{* *} \\
(0.756)\end{array}$ & $\begin{array}{l}0.419^{* * *} \\
(0.134)\end{array}$ & $\begin{array}{c}0.942 \\
(0.227)\end{array}$ \\
\hline Immigrants 5 years residence & $\begin{array}{l}1.407^{* * *} \\
(0.237)\end{array}$ & $\begin{array}{c}4.996 \\
(6.388)\end{array}$ & $\begin{array}{l}1.911^{* *} \\
(0.637)\end{array}$ & $\begin{array}{c}1.005 \\
(0.330)\end{array}$ & $\begin{array}{c}1.098 \\
(0.280)\end{array}$ \\
\hline $\begin{array}{l}\text { N. of observations } \\
\text { (natives }=50,234 \text { ) }\end{array}$ & 2,247 & 73 & 309 & 404 & 1,362 \\
\hline
\end{tabular}

Notes: *** Signifies statistically different from zero at the $1 \%$ level or better, **at the $5 \%$ level or better and *at the $10 \%$ level or better. The values for the dependent variable range from 1 to 22 in the case of men and from 1 to 17 in the case of women. The smallest (highest) value is taken by that occupation or group of occupations with the lowest (higher) average gross hourly earnings as of 2002 (Source: Earnings Structure Survey, EES-02). Estimations also include age, education, indicator for marital status and region dummies (52 province dummies). Standard errors are computed using White’s variance estimator. 
Table 6c

Ordered Logit Estimates - Odd Ratios

Dependent Variable: Occupational Ranking

Secondary Educational Attainment

\begin{tabular}{|c|c|c|c|c|c|}
\hline \multirow{2}{*}{$\begin{array}{l}\text { Comparison Group } \\
\text { (Control Group: Natives) }\end{array}$} & \multicolumn{5}{|c|}{ PANEL A: MEN (22 occupational categories) } \\
\hline & $\begin{array}{c}\text { All } \\
\text { Immigrants }\end{array}$ & EU15 & Non-EU15 & Africa & Latino \\
\hline Immigrants 0 year residence & $\begin{array}{l}0.277^{* * *} \\
(0.013)\end{array}$ & $\begin{array}{l}1.060 \\
(0.195)\end{array}$ & $\begin{array}{l}0.181^{* * *} \\
(0.022)\end{array}$ & $\begin{array}{l}0.257^{* * *} \\
(0.037)\end{array}$ & $\begin{array}{l}0.239^{* * *} \\
(0.015)\end{array}$ \\
\hline Immigrants 1 year residence & $\begin{array}{c}0.914 \\
(0.060)\end{array}$ & $\begin{array}{c}0.882 \\
(0.237)\end{array}$ & $\begin{array}{c}1.007 \\
(0.156)\end{array}$ & $\begin{array}{c}0.778 \\
(0.157)\end{array}$ & $\begin{array}{c}1.063 \\
(0.088)\end{array}$ \\
\hline Immigrants 2 years residence & $\begin{array}{c}1.153 \\
(0.079)\end{array}$ & $\begin{array}{c}0.927 \\
(0.225)\end{array}$ & $\begin{array}{l}1.684^{* * *} \\
(0.269)\end{array}$ & $\begin{array}{c}1.048 \\
(0.185)\end{array}$ & $\begin{array}{c}1.141 \\
(0.104)\end{array}$ \\
\hline Immigrants 3 years residence & $\begin{array}{l}0.330^{* * *} \\
(0.105)\end{array}$ & $\begin{array}{c}0.752 \\
(0.187)\end{array}$ & $\begin{array}{l}1.650^{* * *} \\
(0.314)\end{array}$ & $\begin{array}{c}0.982 \\
(0.180)\end{array}$ & $\begin{array}{l}1.500^{* * *} \\
(0.177)\end{array}$ \\
\hline Immigrants 4 years residence & $\begin{array}{l}1.463 \\
(0.155)\end{array}$ & $\begin{array}{c}1.063 \\
(0.0 .299)\end{array}$ & $\begin{array}{l}2.344^{* * *} \\
(0.582)\end{array}$ & $\begin{array}{c}0.795 \\
(0.186)\end{array}$ & $\begin{array}{l}1.501^{* * *} \\
(0.259)\end{array}$ \\
\hline Immigrants 5 years residence & $\begin{array}{l}1.754^{* * *} \\
(0.202)\end{array}$ & $\begin{array}{c}1.154 \\
(0.366)\end{array}$ & $\begin{array}{l}2.871^{* * *} \\
(0.985)\end{array}$ & $\begin{array}{c}1.273 \\
(0.291)\end{array}$ & $\begin{array}{l}1.636^{* * *} \\
(0.315)\end{array}$ \\
\hline $\begin{array}{l}\text { N. of observations } \\
\text { (natives=279,977) }\end{array}$ & 5,197 & 815 & 1,204 & 1,126 & 3,448 \\
\hline \multirow[b]{2}{*}{$\begin{array}{l}\text { Comparison Group } \\
\text { (Control Group: Natives) }\end{array}$} & \multicolumn{5}{|c|}{ PANEL B : WOMEN (17 occupational categories) } \\
\hline & $\begin{array}{c}\text { All } \\
\text { Immigrants }\end{array}$ & EU15 & Non-EU15 & Africa & Latino \\
\hline Immigrants 0 year residence & $\begin{array}{l}0.148^{* * *} \\
(0.009)\end{array}$ & $\begin{array}{c}0.964 \\
(0.202)\end{array}$ & $\begin{array}{l}0.180^{* * *} \\
(0.024)\end{array}$ & $\begin{array}{l}0.288^{* * *} \\
(0.058)\end{array}$ & $\begin{array}{l}0.108^{* * *} \\
(0.008)\end{array}$ \\
\hline Immigrants 1 year residence & $\begin{array}{c}1.028 \\
(0.087)\end{array}$ & $\begin{array}{c}1.379 \\
(0.443)\end{array}$ & $\begin{array}{c}0.945 \\
(0.180)\end{array}$ & $\begin{array}{c}0.920 \\
(0.337)\end{array}$ & $\begin{array}{c}1.137 \\
(0.115)\end{array}$ \\
\hline Immigrants 2 years residence & $\begin{array}{c}1.031 \\
(0.094)\end{array}$ & $\begin{array}{c}1.006 \\
(0.312)\end{array}$ & $\begin{array}{c}0.741 \\
(0.158)\end{array}$ & $\begin{array}{c}0.853 \\
(0.297)\end{array}$ & $\begin{array}{l}1.123 \\
(0.125)\end{array}$ \\
\hline Immigrants 3 years residence & $\begin{array}{l}1.360^{* * *} \\
(0.142)\end{array}$ & $\begin{array}{c}1.369 \\
(0.445)\end{array}$ & $\begin{array}{c}0.970 \\
(0.249)\end{array}$ & $\begin{array}{c}0.735 \\
(0.227)\end{array}$ & $\begin{array}{l}1.402^{* * *} \\
(0.184)\end{array}$ \\
\hline Immigrants 4 years residence & $\begin{array}{l}1.697^{* * *} \\
(0.217)\end{array}$ & $\begin{array}{c}1.370 \\
(0.505)\end{array}$ & $\begin{array}{c}1.178 \\
(0.435)\end{array}$ & $\begin{array}{c}0.918 \\
(0.430)\end{array}$ & $\begin{array}{l}1.699^{* * *} \\
(0.262)\end{array}$ \\
\hline Immigrants 5 years residence & $\begin{array}{l}2.210^{* * *} \\
(0.319)\end{array}$ & $\begin{array}{l}2.114^{* * *} \\
(0.727)\end{array}$ & $\begin{array}{c}1.594 \\
(0.919)\end{array}$ & $\begin{array}{c}0.893 \\
(0.379)\end{array}$ & $\begin{array}{l}1.745^{* * *} \\
(0.304)\end{array}$ \\
\hline $\begin{array}{l}\text { N. of observations } \\
\text { (natives= 161,217 ) }\end{array}$ & 5,197 & 424 & 748 & 316 & 3,565 \\
\hline
\end{tabular}

Notes: *** Signifies statistically different from zero at the $1 \%$ level or better, **at the $5 \%$ level or better and *at the $10 \%$ level or better. The values for the dependent variable range from 1 to 22 in the case of men and from 1 to 17 in the case of women. The smallest (highest) value is taken by that occupation or group of occupations with the lowest (higher) average gross hourly earnings as of 2002 (Source: Earnings Structure Survey, EES-02). Estimations also include age, education, indicator for marital status and region dummies (52 province dummies). Standard errors are computed using White’s variance estimator. 
Table 6d

Ordered Logit Estimates - Odd Ratios

Dependent Variable: Occupational Ranking

University Education

\begin{tabular}{|c|c|c|c|c|c|}
\hline \multirow{2}{*}{$\begin{array}{l}\text { Comparison Group } \\
\text { (Control Group: Natives) }\end{array}$} & \multicolumn{5}{|c|}{ PANEL A: MEN (22 occupational categories) } \\
\hline & $\begin{array}{c}\text { All } \\
\text { Immigrants }\end{array}$ & EU15 & Non-EU15 & Africa & Latino \\
\hline Immigrants 0 year residence & $\begin{array}{l}0.399^{* * *} \\
(0.059)\end{array}$ & $\begin{array}{c}1.407 \\
(0.298)\end{array}$ & $\begin{array}{l}0.123^{* * *} \\
(0.047)\end{array}$ & $\begin{array}{l}0.229^{* *} \\
(0.191)\end{array}$ & $\begin{array}{l}0.239^{* * *} \\
(0.051)\end{array}$ \\
\hline Immigrants 1 year residence & $\begin{array}{l}0.607^{* * *} \\
(0.121)\end{array}$ & $\begin{array}{c}0.837 \\
(0.280)\end{array}$ & $\begin{array}{c}0.526 \\
(0.246)\end{array}$ & $\begin{array}{c}0.454 \\
(0.439)\end{array}$ & $\begin{array}{c}0.807 \\
(0.220)\end{array}$ \\
\hline Immigrants 2 years residence & $\begin{array}{l}0.603^{* * *} \\
(0.124)\end{array}$ & $\begin{array}{c}0.890 \\
(0.257)\end{array}$ & $\begin{array}{c}0.959 \\
(0.453)\end{array}$ & $\begin{array}{c}0.431 \\
(0.396)\end{array}$ & $\begin{array}{l}0.567^{*} \\
(0.173)\end{array}$ \\
\hline Immigrants 3 years residence & $\begin{array}{c}0.769 \\
(0.179)\end{array}$ & $\begin{array}{c}0.640 \\
(0.198)\end{array}$ & $\begin{array}{c}0.979 \\
(0.758)\end{array}$ & $\begin{array}{c}0.233 \\
(0.221)\end{array}$ & $\begin{array}{c}1.046 \\
(0.341)\end{array}$ \\
\hline Immigrants 4 years residence & $\begin{array}{c}1.111 \\
(0.285)\end{array}$ & $\begin{array}{c}0.904 \\
(0.348)\end{array}$ & $\begin{array}{c}2.130 \\
(1.793)\end{array}$ & $\begin{array}{c}1.081 \\
(1.449)\end{array}$ & $\begin{array}{c}0.996 \\
(0.355)\end{array}$ \\
\hline Immigrants 5 years residence & $\begin{array}{c}1.223 \\
(0.301)\end{array}$ & $\begin{array}{c}0.520 \\
(0.180)\end{array}$ & $\begin{array}{c}6.387 \\
(11.579)\end{array}$ & $\begin{array}{c}0.933 \\
(0.924)\end{array}$ & $\begin{array}{c}1.920 \\
(0.817)\end{array}$ \\
\hline $\begin{array}{l}\text { N. of observations } \\
\text { (natives }=79,830 \text { ) }\end{array}$ & 1,598 & 463 & 190 & 162 & 713 \\
\hline \multirow[b]{2}{*}{$\begin{array}{l}\text { Comparison Group } \\
\text { (Control Group: Natives) }\end{array}$} & \multicolumn{5}{|c|}{ PANEL B : WOMEN (17 occupational categories) } \\
\hline & $\begin{array}{c}\text { All } \\
\text { Immigrants }\end{array}$ & EU15 & Non-EU15 & Africa & Latino \\
\hline Immigrants 0 year residence & $\begin{array}{l}0.118^{* * *} \\
(0.025)\end{array}$ & $\begin{array}{c}1.283 \\
(0.368)\end{array}$ & $\begin{array}{l}0.036^{* * *} \\
(0.016)\end{array}$ & --- & $\begin{array}{l}0.071^{* * *} \\
(0.021)\end{array}$ \\
\hline Immigrants 1 year residence & $\begin{array}{c}0.753 \\
(0.213)\end{array}$ & $\begin{array}{c}0.573 \\
(0.242)\end{array}$ & $\begin{array}{c}1.299 \\
(0.763)\end{array}$ & --- & $\begin{array}{c}0.780 \\
(0.296)\end{array}$ \\
\hline Immigrants 2 years residence & $\begin{array}{l}1.942^{* * *} \\
(0.583)\end{array}$ & $\begin{array}{c}0.933 \\
(0.380)\end{array}$ & $\begin{array}{c}1.681 \\
(1.022)\end{array}$ & -- & $\begin{array}{l}2.300^{* * *} \\
(0.972)\end{array}$ \\
\hline Immigrants 3 years residence & $\begin{array}{l}3.087^{* * *} \\
(0.930)\end{array}$ & $\begin{array}{c}0.693 \\
(0.267)\end{array}$ & $\begin{array}{l}3.668^{* *} \\
(2.525)\end{array}$ & --- & $\begin{array}{l}3.203^{* * *} \\
(1.465)\end{array}$ \\
\hline Immigrants 4 years residence & $\begin{array}{l}3.239^{* * *} \\
(1.211)\end{array}$ & $\begin{array}{c}1.111 \\
(0.498)\end{array}$ & $\begin{array}{l}16.053^{* * *} \\
(14.212)\end{array}$ & --- & $\begin{array}{c}1.413 \\
(0.844)\end{array}$ \\
\hline Immigrants 5 years residence & $\begin{array}{l}3.905^{* * *} \\
(1.289)\end{array}$ & $\begin{array}{c}0.743 \\
(0.321)\end{array}$ & $\begin{array}{l}7.085^{* * *} \\
(7.090)\end{array}$ & --- & $\begin{array}{l}4.319^{* * *} \\
(2.039)\end{array}$ \\
\hline $\begin{array}{l}\text { N. of observations } \\
\text { (natives }=81,782 \text { ) }\end{array}$ & 1,371 & 284 & 233 & 53 & 765 \\
\hline
\end{tabular}

Notes: *** Signifies statistically different from zero at the $1 \%$ level or better, **at the $5 \%$ level or better and *at the $10 \%$ level or better. The values for the dependent variable range from 1 to 22 in the case of men and from 1 to 17 in the case of women. The smallest (highest) value is taken by that occupation or group of occupations with the lowest (higher) average gross hourly earnings as of 2002 (Source: Earnings Structure Survey, EES-02). Estimations also include age, education, indicator for marital status and region dummies (52 province dummies). Standard errors are computed using White’s variance estimator. 
Figure 1

Evolution of Foreign Residents in Spain by Place of Origin, 1995-2004

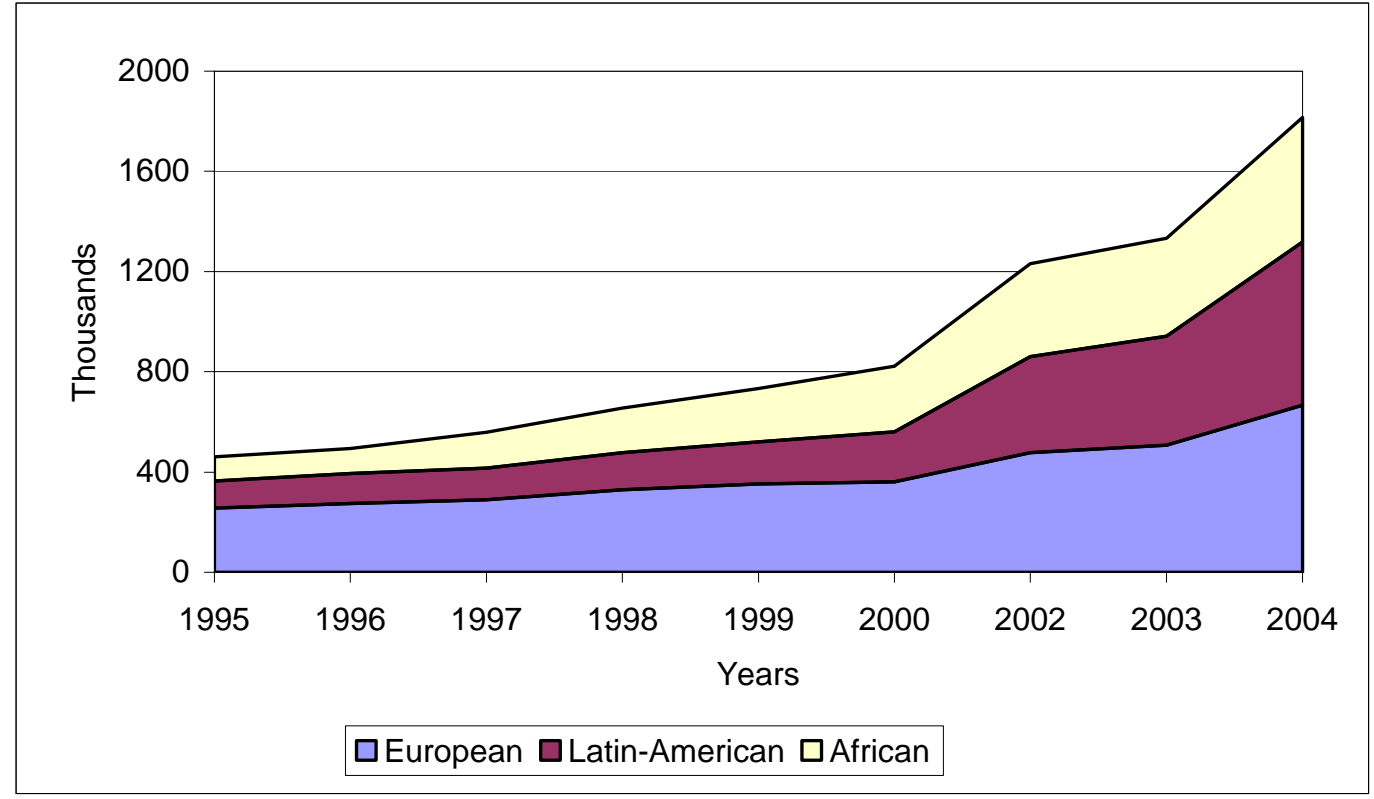

Source: Anuario de Extranjería and Permanent Observatory of Immigration (Immigrants with Residence Permits).

Figure 2

Occupational Distribution All Educational levels - MEN

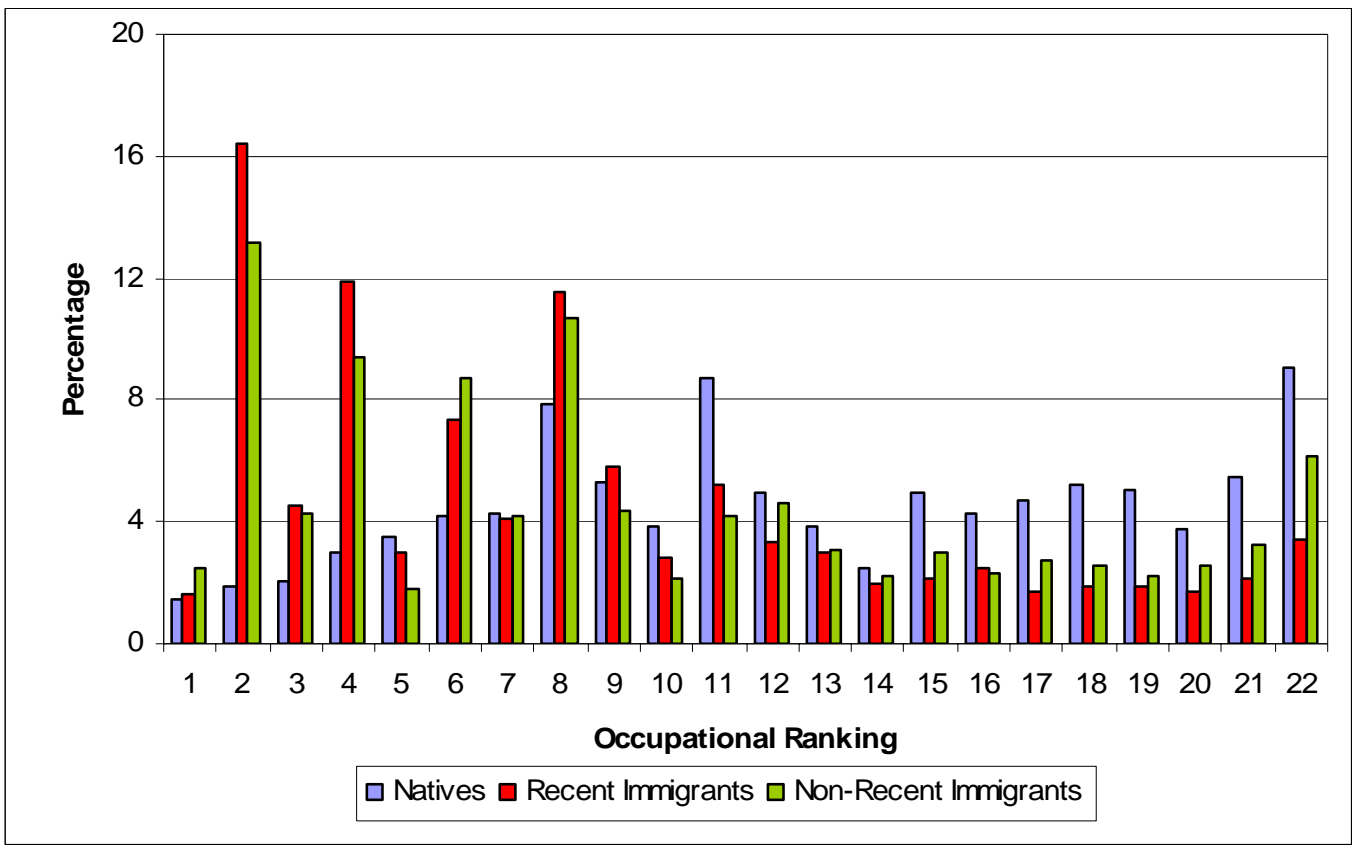


Figure 3

Occupational Distribution - Primary Education or less - MEN

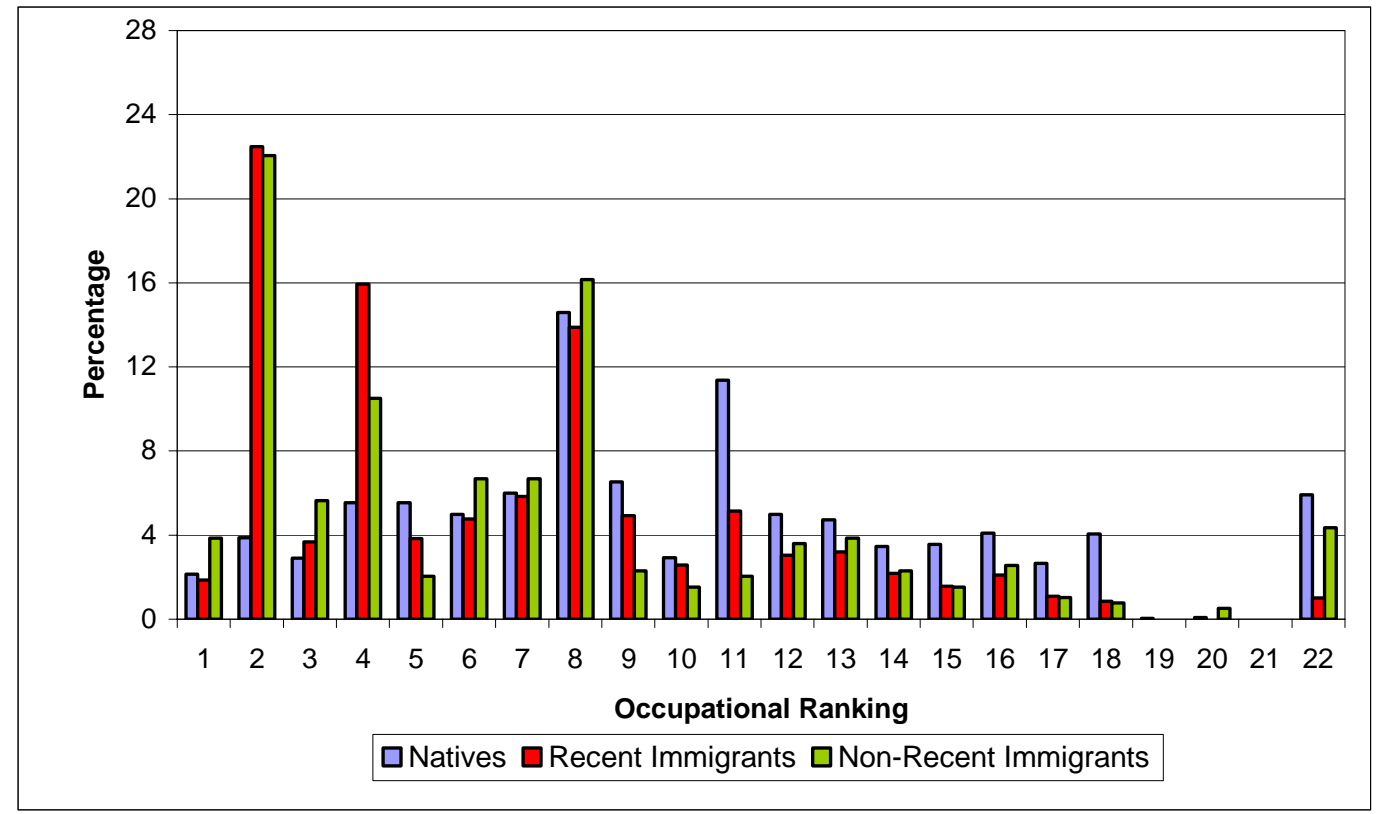

Figure 4

Occupational Distribution - Secondary Education - MEN

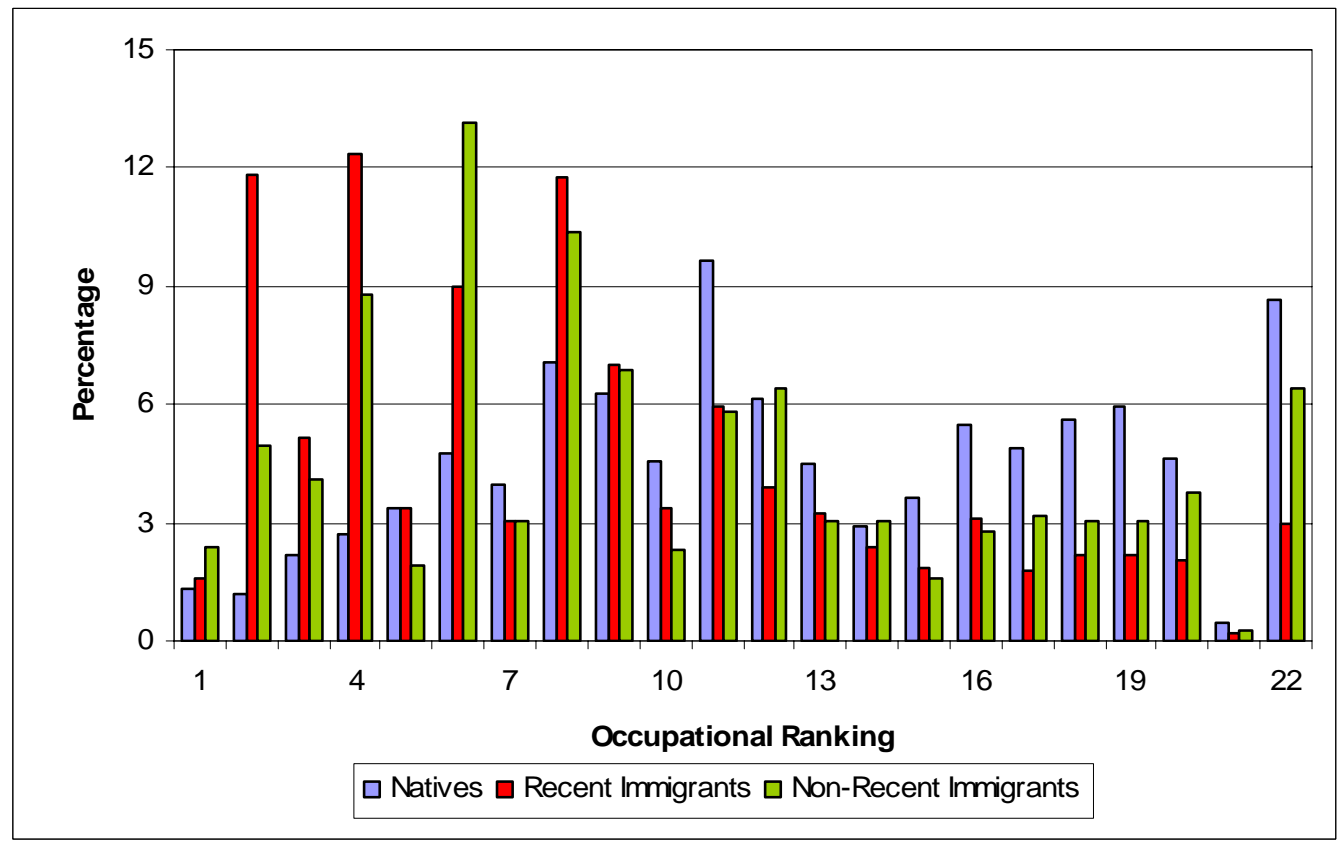


Figure 5

Occupational Distribution - University Education - MEN

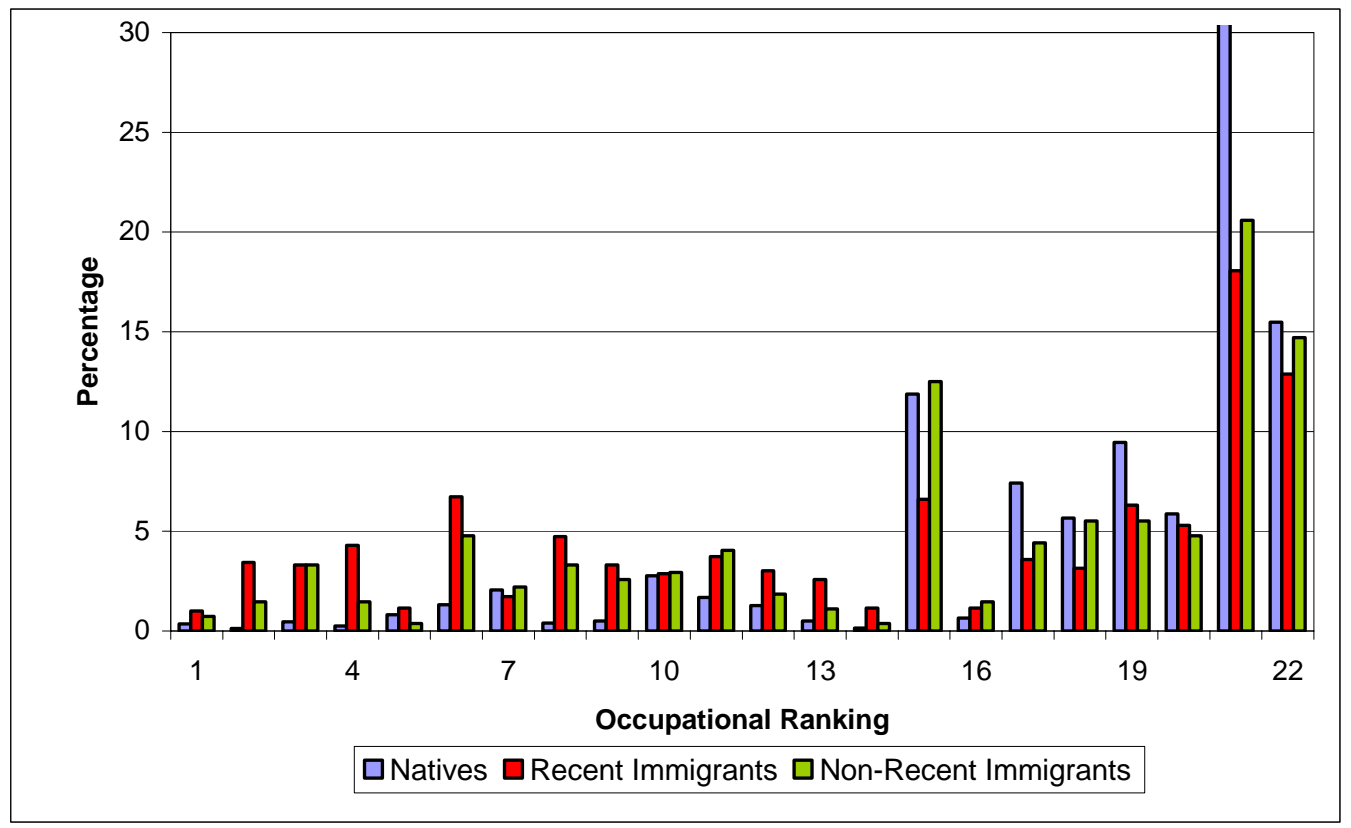

Figure 6

Occupational Distribution - All Educational Levels -WOMEN

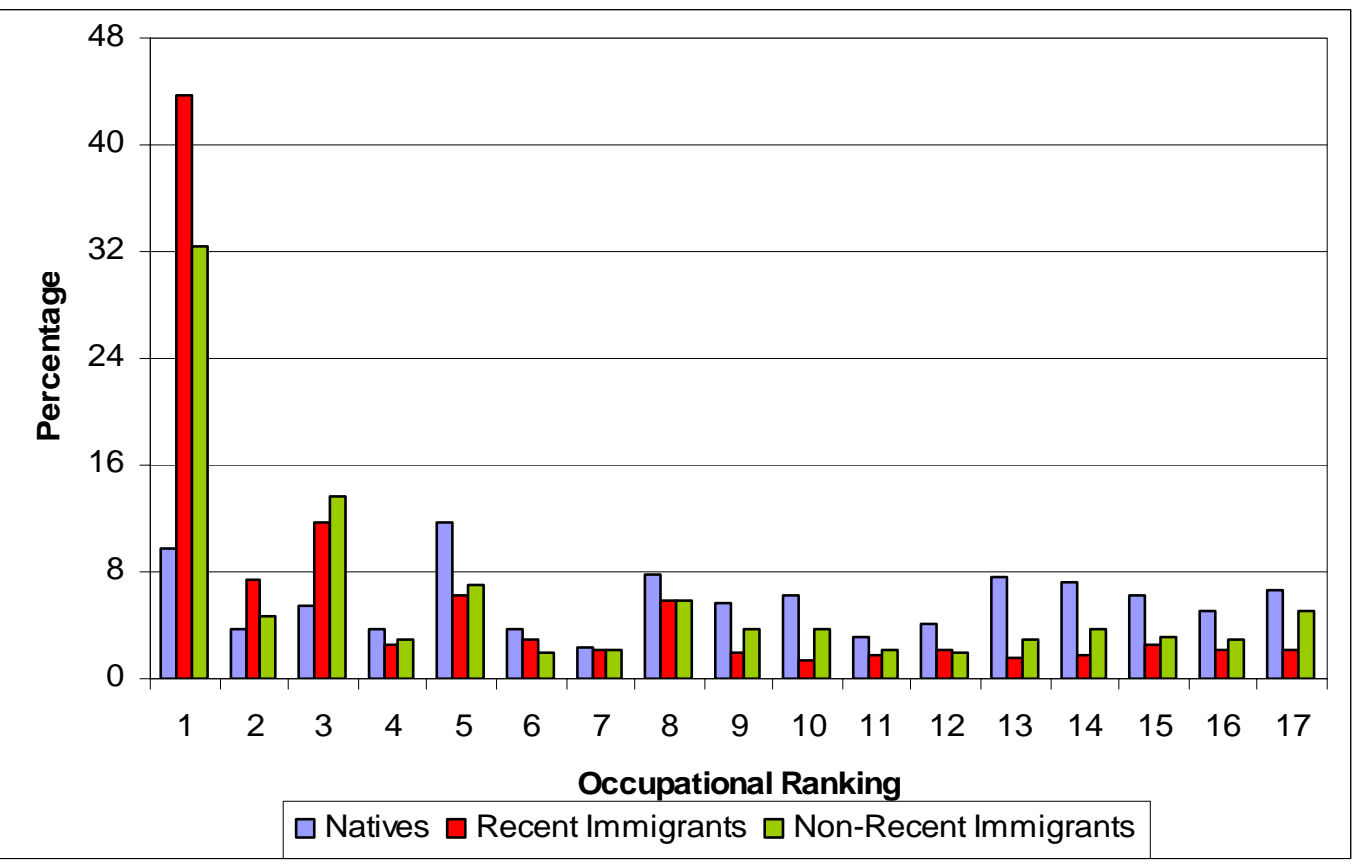


Figure 7

Occupational Distribution - Primary Education or less -WOMEN

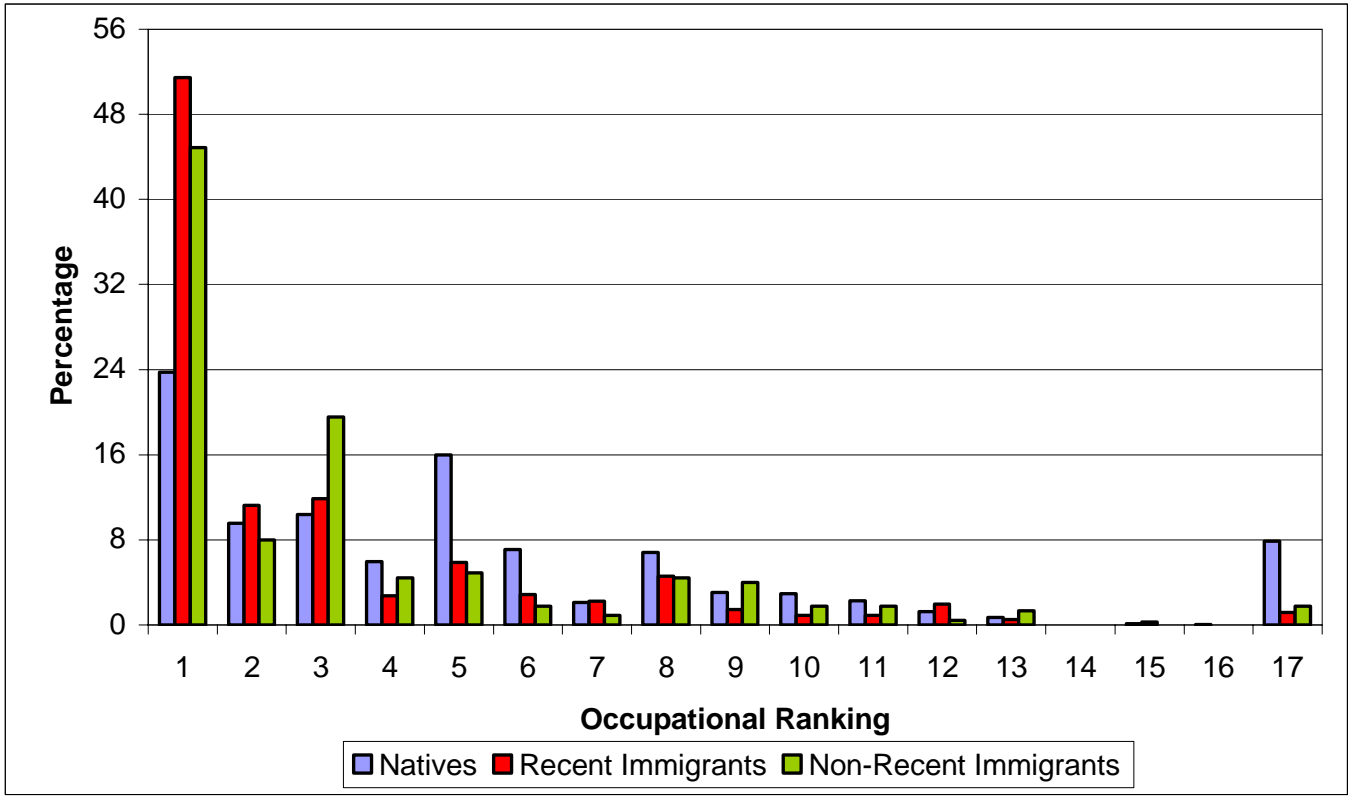

Figure 8

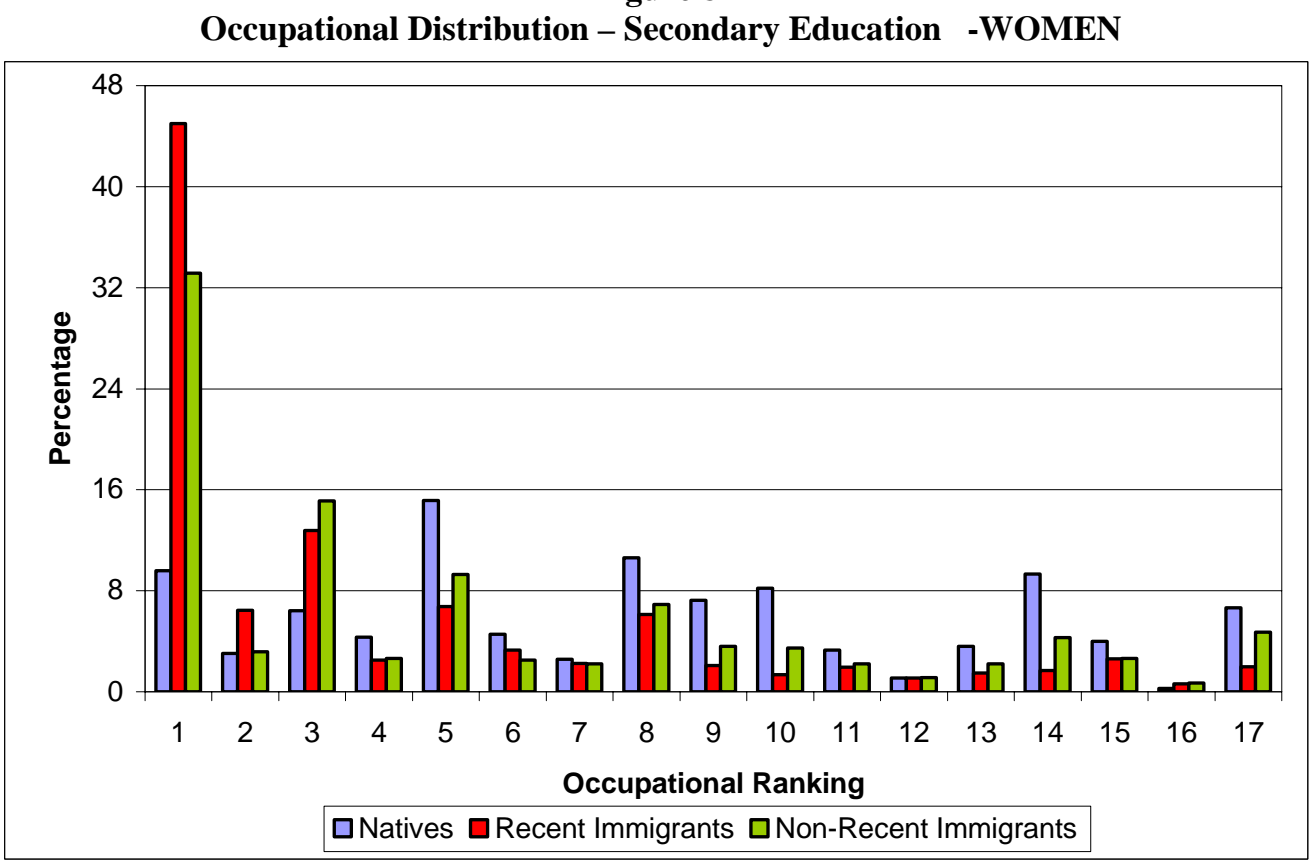


Figure 9

Occupational Distribution - University Education -WOMEN

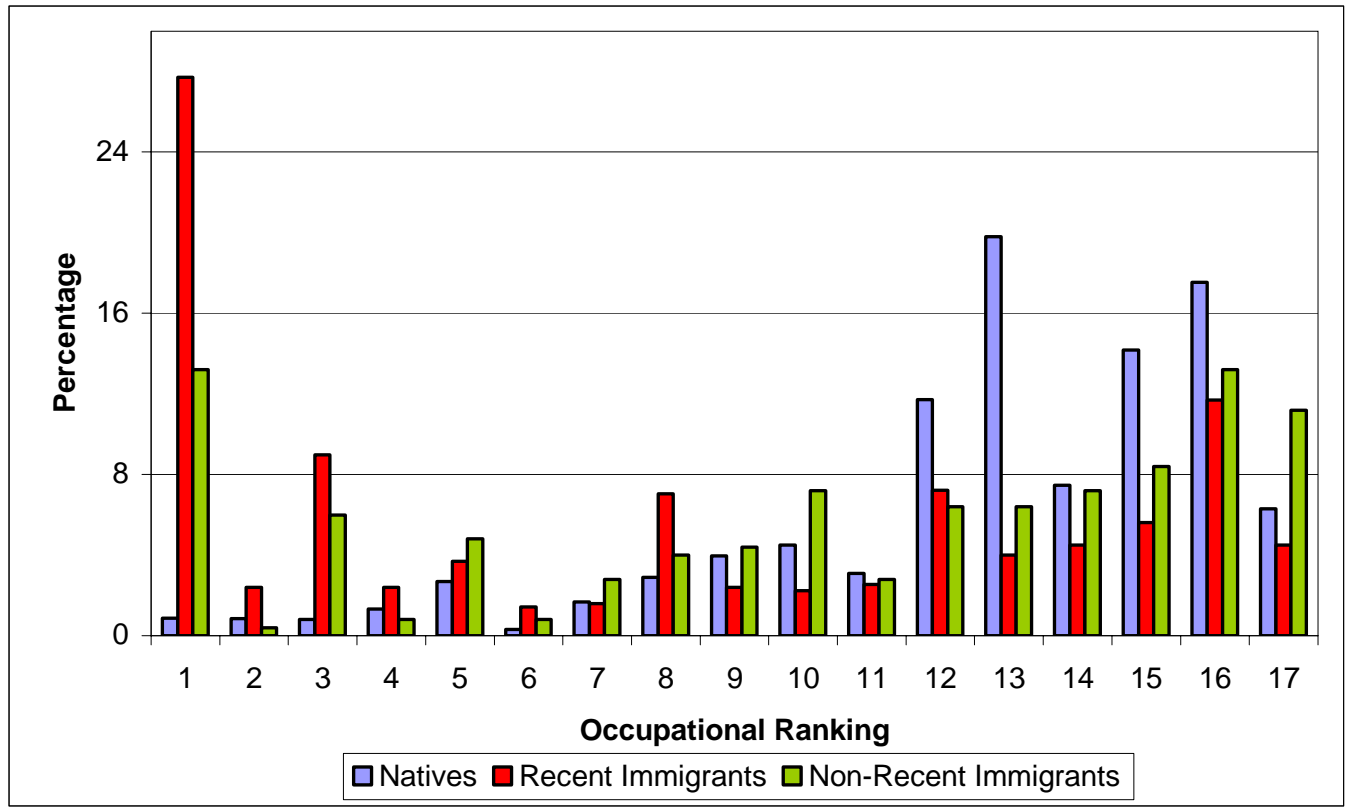

